\title{
Synthesis, structural and antimicrobial studies of some 1-[2-(1H-benzimidazol-1-yl)acetyl]-2,6-diarylpiperidin-4-ones
}

\author{
Gopalakrishnan Aridoss, Shanmugasundaram Amirthaganesan, Min Sung Kim, \\ Byung Gwon Cho, Kwon Taek Lim, and Yeon Tae Jeong*
}

Division of Image Science and Information Engineering, Pukyong National University, Busan, Korea-608-739

E-mail: ytjeong@pknu.ac.kr

\begin{abstract}
A series of 1-[2-(1H-benzimidazol-1-yl)acetyl]-2,6-diarylpiperidin-4-ones (21-30) has been synthesized under mild conditions in good yield. Structural assignments and conformational analysis of the compounds were established through one- $\left({ }^{1} \mathrm{H}\right.$ and $\left.{ }^{13} \mathrm{C}\right)$ and two-dimensional (NOESY and HSQC) NMR studies. A significant upfield shift of proton and carbon at position ' $\mathrm{g}$ ' of the benzimidazole moiety and phenyl ortho protons of the piperidone system is considered to originate from the anisotropic influence of the suitably positioned $\pi$ bond containing amide carbonyl group. Dynamic NMR studies proved the existence of restricted rotation and coplanarity of the amide $\mathrm{N}-\mathrm{C}=\mathrm{O}$ carbonyl group and was further confirmed by $\mathrm{X}$-ray crystallographic study of $\mathbf{2 0}$. Besides, the rotomers resulting from restricted rotation undergo fastest interconversion on NMR time scale at ambient temperature while at low temperatures, slow exchange occurs leading to a set of signals corresponding to cis and trans rotomers with perfectly equal intensity. The possible factors for the non-broadening of the benzimidazole signals even at very low temperature is explained through dynamic NMR studies. Mass spectral studies indicate a common mode of cleavage among the symmetrically and unsymmetrically substituted analogues. Measurement of antimicrobial activity showed that compounds 23, 24 and $\mathbf{2 5}$ exhibited a better activity profile towards the tested microbial strains.
\end{abstract}

Keywords: Piperidones, benzimidazole, dynamic NMR, X-ray analysis, antimicrobial activity

\section{Introduction}

The amides are one of the most significant functional groups in all of chemistry, forming the basic building block of biologically important polymers such as peptides and proteins. Observation of slow cis-to-trans isomerization (hindered $\mathrm{N}-\mathrm{C}=\mathrm{O}$ rotation) about the $\mathrm{C}-\mathrm{N}$ bond in amides and its implications for reactivity and conformation have fascinated chemists for many 
years. Nuclear magnetic resonance (NMR) spectrometry has become one of the paramount techniques for the study of hindered internal rotation in systems in which the rate of interconversion between two rotational conformers is sufficiently slow to allow a chemical shift difference between signals arising from two rotomers. ${ }^{1}$ Various factors are known to influence the chemical shifts of the protons in a molecule. One of these factors is the anisotropic effect notably observed in alkenes, ketones/aldehydes, alkynes and aromatic compounds.

Our ongoing research effort is devoted to discover potential 2,6-diarylpiperidin-4-one based chemical entities as antimicrobial agents ${ }^{2}$ and establishing their stereochemistry, ${ }^{3}$ because, the pharmacological effects of potential drugs depends sensitively on the stereochemistry and ring conformations especially in the case of 2,6-disubstituted-4-piperidones as they could serve as precursors of chiral biologically active and natural alkaloids. ${ }^{4}$

In this paper, we report the synthesis of diversely substituted 2,6-diarylpiperidin-4-ones based on 1[H-benzimidazol-1-yl]acetyl amides via a three-step synthetic pathway. Benzimidazole derivatives were chosen mainly because they are structural isosteres of naturally occurring nucleotides, which allows them to interact easily with the biopolymers of the living systems. Consequently, they exhibit numerous biological activities such as diuretic, ${ }^{5}$ antifungal, ${ }^{6}$ antiallergic, antimicrobial ${ }^{7}$ and antiviral. ${ }^{8}$ Structural elucidation and conformations of the synthesized compounds were determined through IR, Mass, ${ }^{1} \mathrm{H}$ and ${ }^{13} \mathrm{C}$ NMR spectral studies. The unambiguous assignments of all carbons and the associated protons were achieved through two dimensional NMR experiments, viz. NOESY and heteronuclear correlated spectroscopic experiments. The existence of restricted rotation about the $\mathrm{N}-\mathrm{C}=\mathrm{O}$ bond and its coplanarity in this set of molecules was also established on the basis of dynamic NMR studies recorded for the representative compound $\mathbf{2 9}$ over a wide range of temperatures i.e., from $293-218 \mathrm{~K}\left(+20^{\circ} \mathrm{C}\right.$ to $55^{\circ} \mathrm{C}$ ). Conformations of the target compounds were ascertained by X-ray crystallographic studies of compound 20. All the synthesized compounds were also preliminarily evaluated for their possible antimicrobial activity against selected bacterial and fungal strains.

\section{Results and Discussion}

The methods for $N$-alkylation of benzimidazole are well documented and established, thus $N$-alkylation can be effected with $\mathrm{K}_{2} \mathrm{CO}_{3} / \mathrm{DMF}, \mathrm{NaH} / \mathrm{DMF},{ }^{9} \mathrm{TBAB} / \mathrm{NEt}_{3} / \mathrm{CH}_{3} \mathrm{CN},{ }^{10}$ $\mathrm{K}_{2} \mathrm{CO}_{3} /$ acetone, ${ }^{11} \mathrm{Cs}_{2} \mathrm{CO}_{3} /$ acetone, $\mathrm{NaH} / \mathrm{DMF}, \mathrm{BTPP} / \mathrm{THF}^{12}$ or microwave irradiation ${ }^{13}$ etc. Recently, it is also reported that $N$-alkylation of benzimidazole needs a dry argon atmosphere, a long reaction time and a low temperature. ${ }^{14}$ In this paper, we report the $N$-alkylation of benzimidazole in good yield (81-92\%) using $\mathrm{K}_{2} \mathrm{CO}_{3} / \mathrm{DMF}^{9}$ at room temperature (Scheme 1) though chlorides were less reactive than other halides. 


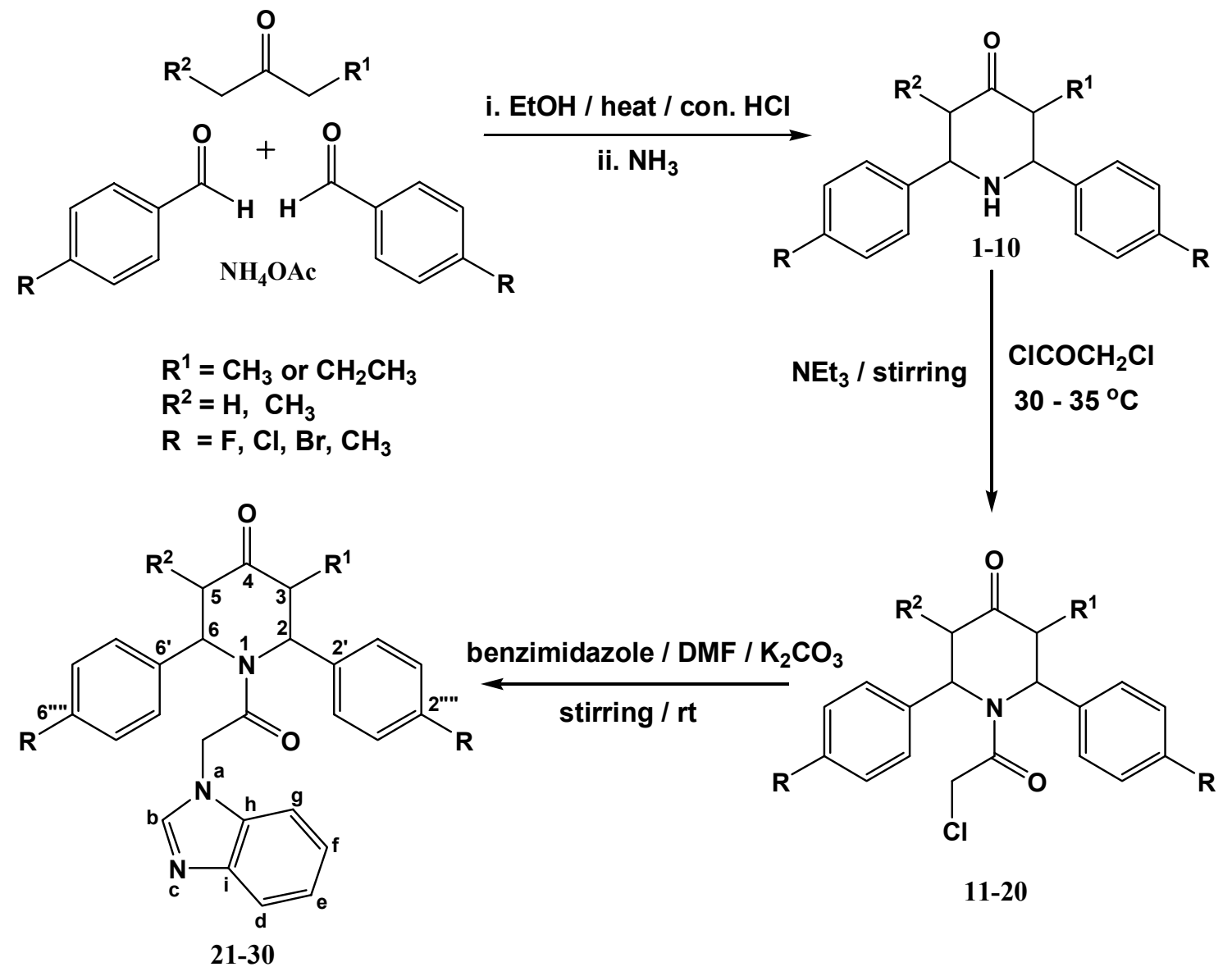

Scheme 1. Synthesis of 1-[2-(1H-benzimidazol-1-yl)acetyl]-2,6-diarylpiperidin-4-ones

\section{IR and elemental analysis}

IR spectrum of the representative compound 21 showed medium intense bands at 3057, 3031, 2968 and $2931 \mathrm{~cm}^{-1}$ characteristic for aromatic and aliphatic C-H stretching vibrations. The two strong absorption bands appeared at 1711 and $1651 \mathrm{~cm}^{-1}$ respectively are attributed to ketone and amide carbonyl groups. Elemental $(\mathrm{CHN})$ analysis for the target compounds 21-30 gave observed values well within $\pm 0.4 \%$ from the calculated values.

\section{NMR spectral analysis}

All the synthesized compounds were investigated by ${ }^{1} \mathrm{H}$ and ${ }^{13} \mathrm{C}$ NMR and were further confirmed beyond doubt with two dimensional NMR (NOESY and HSQC) recorded for the representative compounds 21 and 29. Among the compounds under study, the set of symmetrically $(23,25,27,29$ and 30) and unsymmetrically (21, 22, 24, 26 and 28) substituted compounds differ significantly in their proton and carbon NMR resonances for the piperidone moiety whereas, chemical shifts of the benzimidazole ring and acetyl methyl group are nearly same in both the set of compounds. 


\section{${ }^{1}$ H NMR spectral studies}

NMR analysis and conformation of the target compounds were made by comparison with some of the intermediate compounds (11-13, 16 and 17) reported earlier by us. ${ }^{3}$ The observation of a broad singlet for the benzylic protons H-2 and H-6 of 21-30 in the most downfield region (5.28$6.13 \mathrm{ppm}$ ) suggests the existence of restricted rotation about $\mathrm{N}-\mathrm{C}=\mathrm{O}$ bond (Scheme 2).

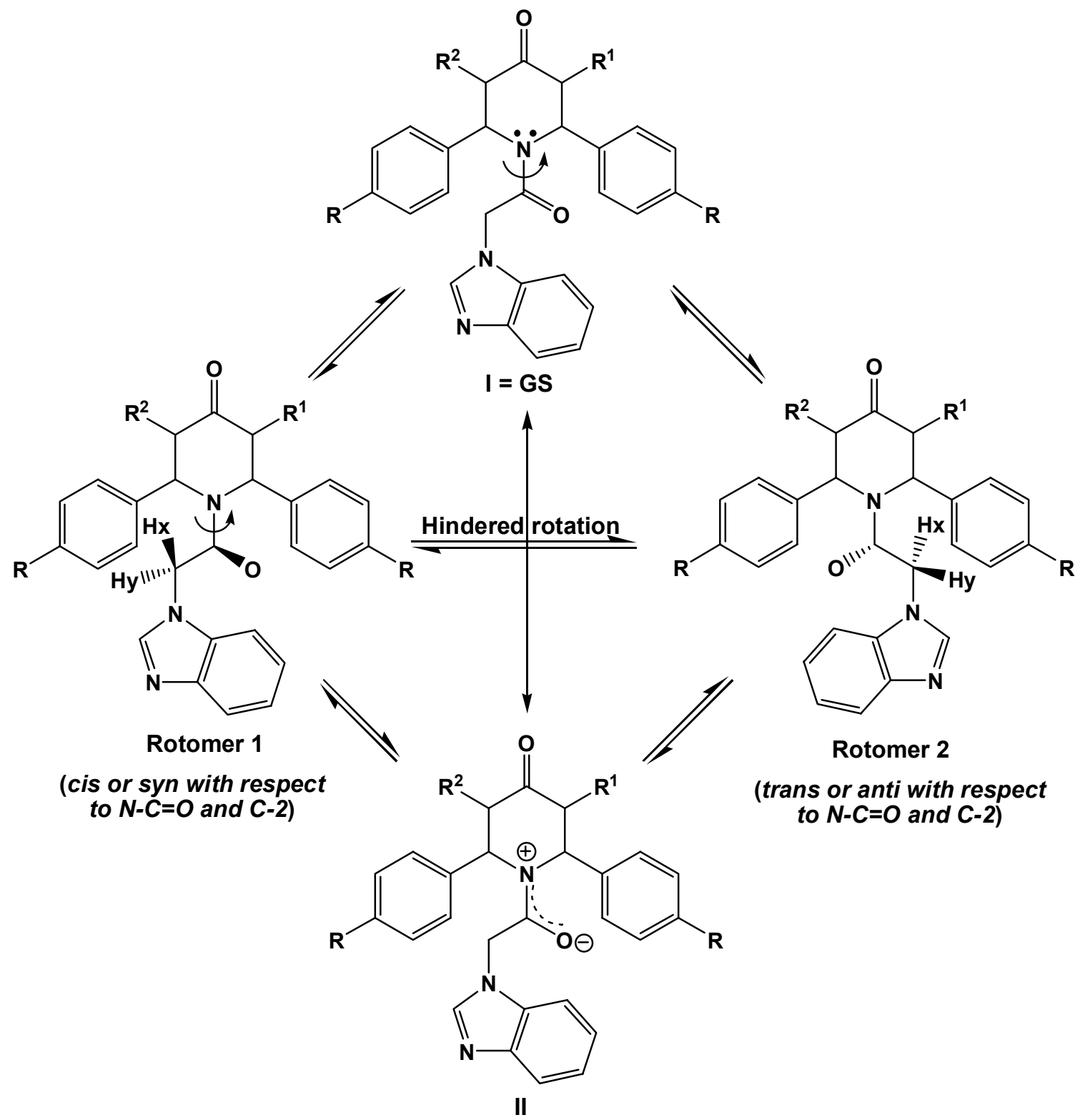

Scheme 2. Restricted rotation about $\mathrm{N}-\mathrm{C}=\mathrm{O}$ in piperidone amides 21-30 (I=GS-Ground state; IInitrogen lone pair delocalization).

However, the signals due to the other protons in both heterocyclic systems in the molecule displayed well-resolved signals which allowed for the precise determination of coupling constant 
values and consequently their conformations. It is obvious that due to slow amide rotation, the chemical shift and coupling constant (Table 1) values of the piperidone ring protons are notably changed from their corresponding values in their parent 2,6-diarylpiperidin-4-ones like their respective intermediates.

Compound $\mathbf{2 1}$ was taken as a typical compound for complete proton NMR characterization. Here, a doublet centered at $1.07 \mathrm{ppm}(J=6.59 \mathrm{~Hz})$ with three protons integral is assigned to methyl group at C-3 while two doublets at $4.66(J=17.21 \mathrm{~Hz})$ and $4.75 \mathrm{ppm}(J=16.84 \mathrm{~Hz})$ correspond to acetyl methylene protons ( $\mathrm{Hx}$ and $\mathrm{Hy})$.

Table 1. Vicinal and geminal coupling constants (Hz) of compounds 21-30

\begin{tabular}{|c|c|c|c|c|c|c|c|c|c|c|}
\hline Entry & ${ }^{2} J_{5 \mathrm{a}, 5 \mathrm{e}}$ & ${ }^{2} J_{5 \mathrm{e}, 5 \mathrm{a}}$ & ${ }^{3} J_{5 \mathrm{a}, 6 \mathrm{a}}$ & ${ }^{3} J_{5 \mathrm{e}, 6 \mathrm{a}}$ & ${ }^{3} J_{3 \mathrm{a}, 2 \mathrm{a}}$ & ${ }^{2} J_{\mathrm{Hx}, \mathrm{Hy}}$ & ${ }^{2} J_{\mathrm{Hy}, \mathrm{Hx}}$ & $J_{\mathrm{Me}, \mathrm{H}}$ & $J_{\mathrm{g}, \mathrm{f}}$ & $J_{\mathrm{d}, \mathrm{e}}$ \\
\hline 21 & $\begin{array}{c}18.31 \\
(18.22)\end{array}$ & $\begin{array}{c}18.49 \\
(18.22)\end{array}$ & $\begin{array}{c}5.49 \\
(6.10)\end{array}$ & $\begin{array}{c}6.04 \\
(5.91)\end{array}$ & $\begin{array}{c}7.08 \\
(7.01)\end{array}$ & $\begin{array}{c}17.21 \\
(12.72)\end{array}$ & $\begin{array}{c}16.84 \\
(12.62)\end{array}$ & $\begin{array}{c}6.59 \\
(6.62)\end{array}$ & 7.32 & 7.72 \\
\hline 22 & $\begin{array}{c}17.58 \\
(17.25)\end{array}$ & $\begin{array}{c}17.58 \\
(17.38)\end{array}$ & $\begin{array}{c}9.89 \\
(9.31)\end{array}$ & $\begin{array}{c}5.49 \\
(5.57)\end{array}$ & $\begin{array}{c}3.51 \\
(3.49)\end{array}$ & $\begin{array}{c}16.84 \\
(12.47)\end{array}$ & $\begin{array}{c}16.84 \\
(12.49)\end{array}$ & $\begin{array}{c}7.34^{*} \\
(7.29)^{*}\end{array}$ & 7.32 & 7.69 \\
\hline 23 & - & - & $\begin{array}{c}6.87 \\
(6.71)\end{array}$ & - & $\begin{array}{c}6.87 \\
(6.71)\end{array}$ & - & - & $\begin{array}{c}6.59 \\
(6.84)\end{array}$ & 7.69 & 7.69 \\
\hline 24 & $\begin{array}{c}18.31 \\
(18.12)\end{array}$ & $\begin{array}{c}18.49 \\
(18.31)\end{array}$ & $\begin{array}{c}5.13 \\
(5.13)\end{array}$ & $\begin{array}{c}6.04 \\
(6.22)\end{array}$ & $\begin{array}{c}7.05 \\
(5.95)\end{array}$ & $\begin{array}{l}16.84 \\
(X X)^{a}\end{array}$ & $\begin{array}{l}16.84 \\
(X X)\end{array}$ & $\begin{array}{c}6.59 \\
(6.86)\end{array}$ & 7.32 & 6.96 \\
\hline 25 & - & - & $\begin{array}{c}6.77 \\
(6.68)\end{array}$ & - & $\begin{array}{c}6.77 \\
(6.68)\end{array}$ & - & - & $\begin{array}{c}6.96 \\
(6.96)\end{array}$ & 7.32 & 7.69 \\
\hline 26 & $\begin{array}{c}18.12 \\
(18.13)\end{array}$ & $\begin{array}{c}18.16 \\
(18.17)\end{array}$ & $\begin{array}{c}5.31 \\
(5.46)\end{array}$ & $\begin{array}{c}5.89 \\
(6.02)\end{array}$ & $\begin{array}{c}7.05 \\
(6.90)\end{array}$ & $\begin{array}{l}16.84 \\
(\mathrm{XX})\end{array}$ & $\begin{array}{l}16.84 \\
(X X)\end{array}$ & $\begin{array}{c}6.96 \\
(6.63)\end{array}$ & 6.96 & XX \\
\hline 27 & - & - & $\begin{array}{c}6.77 \\
(6.71)\end{array}$ & - & $\begin{array}{c}6.77 \\
(6.71)\end{array}$ & - & - & $\begin{array}{c}6.96 \\
(6.91)\end{array}$ & 7.69 & 7.69 \\
\hline 28 & $\begin{array}{c}18.31 \\
(18.31)\end{array}$ & $\begin{array}{c}18.49 \\
(18.12)\end{array}$ & $\begin{array}{c}5.13 \\
(5.49)\end{array}$ & $\begin{array}{c}6.04 \\
(6.04)\end{array}$ & $\begin{array}{c}7.14 \\
(6.77)\end{array}$ & $\begin{array}{l}16.84 \\
(\mathrm{XX})\end{array}$ & $\begin{array}{l}16.84 \\
(\mathrm{XX})\end{array}$ & $\begin{array}{c}6.59 \\
(6.59)\end{array}$ & 6.96 & XX \\
\hline 29 & - & - & $\begin{array}{c}6.87 \\
(6.77)\end{array}$ & - & $\begin{array}{c}6.87 \\
(6.77)\end{array}$ & - & - & $\begin{array}{c}6.96 \\
(6.96)\end{array}$ & 6.96 & 7.69 \\
\hline 30 & - & - & $\begin{array}{c}6.68 \\
(6.77)\end{array}$ & - & $\begin{array}{c}6.68 \\
(6.77)\end{array}$ & - & - & $\begin{array}{c}6.96 \\
(6.96)\end{array}$ & 7.69 & 7.69 \\
\hline
\end{tabular}

Values in the parenthesis correspond to respective chloroacetyl derivative.

* Coupling with methylene $\left(\underline{\mathrm{CH}}_{2} \mathrm{CH}_{3}\right)$ protons. ${ }^{\text {a Not resolved. }}$

Downfield shift of acetyl methylene protons compared to its corresponding precursor $\mathbf{1 1}$ is attributed to the replacement of chlorine by more electron-withdrawing benzimidazole system. Moreover, the magnitude of coupling constant values suggests that these two protons are diastereotopic. In the aliphatic region, there were two well-resolved double doublets and a quintet centered respectively at $2.86(J=18.49 / 6.04 \mathrm{~Hz}), 3.24(J=18.31 / 5.49 \mathrm{~Hz})$ and $3.11 \mathrm{ppm}$ 
$(J=7.08 \mathrm{~Hz})$. On the basis of observed nOes and coupling constant values, these are definitely assigned to $\mathrm{H}-5 \mathrm{e}, \mathrm{H}-5 \mathrm{a}$ and $\mathrm{H}-3 \mathrm{a}$ protons. Deshielding of $\mathrm{H}-5 \mathrm{a}$ by about 0.4 ppm compared to $\mathrm{H}-5 \mathrm{e}$ can be accounted for by considering its electronic interaction with the spatially close phenyl group at $\mathrm{C}-2$. In the other 3-methyl-substituted analogues, the piperidone ring protons are assigned similarly, since they exhibited identical splitting patterns. However, in compounds with methyl groups at C-3 and C-5 (23, 25, 27, 29 and 30), the signal due to the methine protons of respective carbons appeared as well resolved quintets while the acetyl methylene protons as sharp singlets owing to their symmetrical nature.

Besides piperidone ring signals, there were two well-resolved doublets (at 6.74 and 7.77 $\mathrm{ppm}$ ), an intense singlet (7.72 ppm), unresolved doublet (7.16 ppm) and a multiplet (7.19-7.30 $\mathrm{ppm})$ in the aromatic region. Here, the well-resolved doublets and singlet correspond to one proton each, while the multiplet corresponds to two protons.

Table 2. Correlations in NOESY (for 21) and HSQC (for 29) spectra of compounds 21 and 29 $[\delta(\mathrm{ppm})]$

\begin{tabular}{|c|c|c|c|c|c|}
\hline Entry & $\begin{array}{l}\text { Proton NMR } \\
\text { chemical shift }\end{array}$ & $\begin{array}{l}\text { Correlations in the } \\
\text { NOESY spectrum }\end{array}$ & Entry & $\begin{array}{l}\text { Carbon } \\
\text { NMR } \\
\text { chemical } \\
\text { shift }\end{array}$ & $\begin{array}{l}\text { Correlations (with } \\
\text { proton chemical } \\
\text { shifts) in the HSQC } \\
\text { spectrum }\end{array}$ \\
\hline \multirow{11}{*}{21} & $1.07(\mathrm{~d}, 3 \mathrm{H})$ & $3.11,7.16(\mathrm{w})^{*}$ & \multirow{11}{*}{29} & 14.14 & $\mathrm{CH}_{3}$ at $\mathrm{C}-3$ and $\mathrm{C}-5$ \\
\hline & $2.86(\mathrm{dd}, 1 \mathrm{H})$ & 3.24 & & 45.21 & $\mathrm{H}-3 \mathrm{a}$ and $\mathrm{H}-5 \mathrm{a}$ \\
\hline & $3.11(\mathrm{q}, 1 \mathrm{H})$ & $1.07,7.16$ & & 46.72 & $\mathrm{~N}-\mathrm{COCH} \underline{\mathrm{H}}_{2}$ \\
\hline & $3.24(\mathrm{dd}, 1 \mathrm{H})$ & 2.86 & & 60.84 & $\mathrm{H}-2$ and $\mathrm{H}-6$ \\
\hline & $4.66(\mathrm{~d}, 1 \mathrm{H})$ & $\begin{array}{c}4.75,6.74,7.72(\mathrm{w}) \\
7.16\end{array}$ & & 108.66 & H-g \\
\hline & $4.75(\mathrm{~d}, 1 \mathrm{H})$ & $\begin{array}{c}4.66,6.74,7.72(\mathrm{w}), \\
7.16\end{array}$ & & 120.34 & $\mathrm{H}-\mathrm{d}$ \\
\hline & $6.74(\mathrm{~d}, 1 \mathrm{H})$ & $\begin{array}{c}4.66,4.75,7.77(\mathrm{w}), \\
7.19-7.17\end{array}$ & & 122.49 & H-f \\
\hline & $\begin{array}{l}7.16[\mathrm{~d}(\text { not } \\
\text { resolved), } 2 \mathrm{H}]\end{array}$ & $\begin{array}{c}1.07(\mathrm{w}), 3.11,4.66 \\
4.75\end{array}$ & & 123.23 & H-e \\
\hline & $7.19-7.30(\mathrm{~m}, 2 \mathrm{H})$ & $6.74,7.77$ & & 129.12 & Proton at C-2"/C-6" \\
\hline & $7.72(\mathrm{~s}, 1 \mathrm{H})$ & $4.66,4.75$ & & 132.36 & $\begin{array}{c}\text { Proton at C-2"'/C- } \\
6 ",\end{array}$ \\
\hline & $7.77(\mathrm{~d}, 1 \mathrm{H})$ & 6.74 .7 .16 & & 143.77 & $\mathrm{H}-\mathrm{b}$ \\
\hline
\end{tabular}

* weak nOe. 
Based on the earlier report ${ }^{14}$ on benzimidazole system and integral values, the singlet at 7.72 ppm should be due to the H-b proton while the multiplet at about 7.19-7.30 ppm must be attributed to two of the benzimidazole protons viz., H-f and H-e. This is also further confirmed by the noted nOes between $\mathrm{H}-\mathrm{b}$ and $\mathrm{Hx} / \mathrm{Hy}$ protons (Table 2).

The unassigned signals left in this moiety are the two doublets at 6.74 and $7.77 \mathrm{ppm}$. These are assigned to two of the ortho protons with respect to ipso carbons $\mathrm{C}-\mathrm{h}$ and $\mathrm{C}-\mathrm{i}$ viz. either $\mathrm{H}-\mathrm{g}$ and $\mathrm{H}-\mathrm{d}$ or $\mathrm{H}-\mathrm{d}$ and $\mathrm{H}-\mathrm{g}$ protons respectively. This is because the magnitude of coupling constant values reveals the existence of ortho coupling (with respect to multiplicity). However, the precise assignment of these signals warrants explanation as one of the signal is shielded by about $1 \mathrm{ppm}$. It is expected from Figure 1 that the chemical shift of the H-g proton seems to resonate in the low field region compared to the $\mathrm{H}-\mathrm{d}$ proton as the former is in the vicinity of the more electronegative carbonyl group.

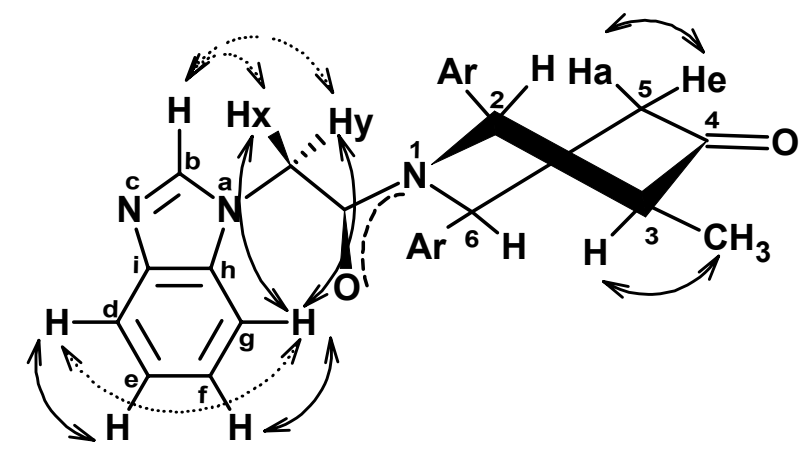

Figure 1. Selected NOE correlations in compound 21 (bold line - strong NOE; dotted line waek NOE):

Contrary to our expectation, the NOESY spectrum of this compound exhibited strong nOes between the doublet at $6.74 \mathrm{ppm}$ and $\mathrm{Hx} / \mathrm{Hy}$ protons only but no nOe was found from the doublet at $7.74 \mathrm{ppm}$ with $\mathrm{Hx} / \mathrm{Hy}$. Therefore, the doublet at $6.74 \mathrm{ppm}$ can be assigned unambiguously to $\mathrm{H}-\mathrm{g}$ and not to H-d. Similarly, the poorly-resolved doublet centered at $7.16 \mathrm{ppm}$ can be assigned to phenyl ortho protons at C-6" (ortho to phenyl ipso carbons) as it showed a strong nOe with $\mathrm{Hx} / \mathrm{Hy}$ and $\mathrm{H}-3 \mathrm{a}$ protons. Further, it is also identified by its two-proton integral value. However, this analogy may not be applicable to 3,5-dimethyl substituted derivatives $(\mathbf{2 3}, \mathbf{2 5}, \mathbf{2 7}, 29$ and 30) because of their symmetrical nature but may be applicable to the 3-ethyl derivative (22) where ortho protons of C-2" are believed to be shielded due to changes in the assumed conformations. The remarkable upfield shift of H-g and phenyl ortho protons clearly shows that these covalently bonded hydrogen nuclei do not lie coplanar with the carbonyl group. Instead, it should be located over the plane of carbonyl group (i.e., it is assumed to be just beyond the carbonyl carbon and away from oxygen). Owing to this, these protons experience a shielding effect arising out of the magnetic anisotropy of the carbon-oxygen double bond in a strong magnetic field. The upfield shift of H-g and phenyl ortho protons is illustrated in Figure 2 with the familiar "shielding cones" 
model ${ }^{15}$ where the said protons are held inside the cones and well shielded. The McConnell equation ${ }^{16,17}$ and other computational methods ${ }^{18}$ also predict shielding of protons above the plane of a $\pi$-bond-containing functional group. Moreover, the relative position of $\mathrm{H}-\mathrm{g}$ and phenyl ortho protons over the carbonyl plane is further supported by their strong nOes with acetyl methylene protons (Hx/Hy) [Table 2].

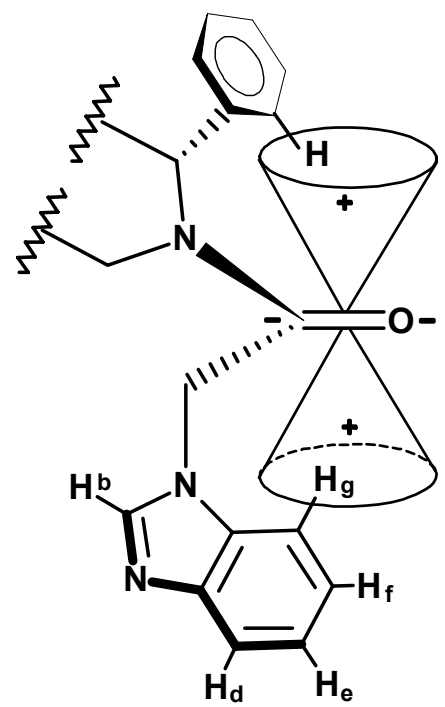

Figure 2. Shielding $(+)$ of protons.

\section{${ }^{13}$ C NMR spectral studies}

The assignments of piperidone ring carbon signals were made in comparison with the earlier report. ${ }^{3}$ However, the signal due to $\mathrm{C}-3$ and acetyl methylene carbon could not be assigned precisely by comparison as they differ in their chemical shift values by about $0.5-1 \mathrm{ppm}$. Hence, for the unambiguous analysis of the resonances due to $\mathrm{C}-3,-\mathrm{COCH}_{2}$ and benzimidazole carbons, HSQC spectrum was recorded for the symmetrically substituted derivative $\mathbf{2 9}$ and is displayed in Figure $3\left({ }^{1} \mathrm{H}\right.$ and ${ }^{13} \mathrm{C}$ NMR of 29 are reproduced in Figures $\mathrm{S} 1$ and $\mathrm{S} 2$ respectively in supplementary files). The selection of this compound for HSQC analysis is mainly due to the fact that each signal in the aromatic region of its proton NMR spectrum is well separated and resolved, which in turn allows for the precise assignment of carbon signals to the corresponding protons. Based on the HSQC correlations (Table 2) of compound 29, the signal in the region 46.56-47.03 is assigned to $-\mathrm{COCH} 2$ carbon while the small upfield signal in the region 45.21$46.28 \mathrm{ppm}$ is characteristic for C-3. Also, among the two aromatic signals at about 108 and 120 ppm, the upfield signal is due to C-g while the downfield one is due to C-d. 


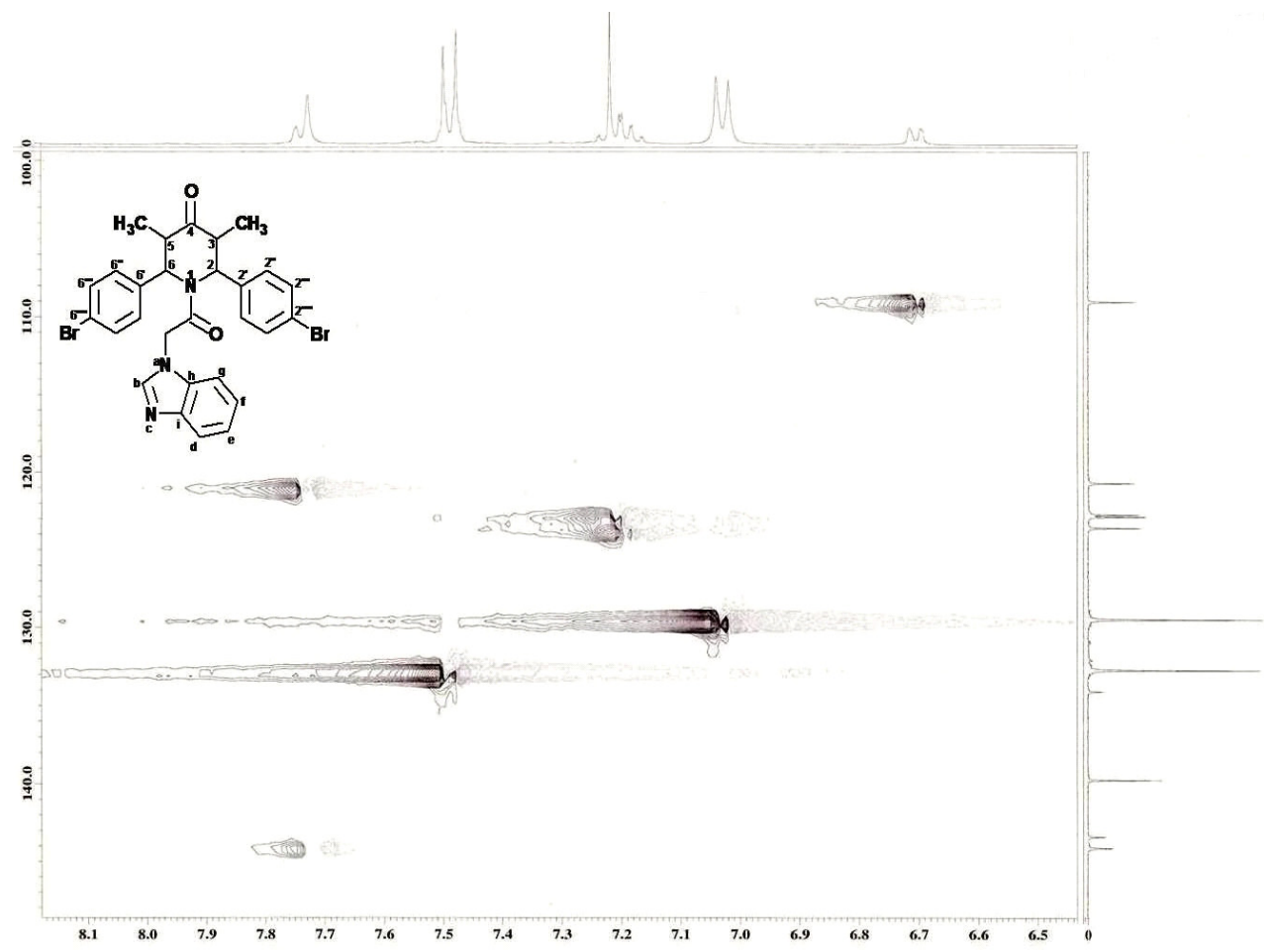

Figure 3. HSQC spectrum of compound 29.

Likewise, assignments of C-f and C-e carbon resonances were made. Since, H-g is located over the plane, C-g carbon may tend to lie in the amide carbonyl plane and shielded well by electronic and steric interactions. On the basis of a previous study ${ }^{14}$ and intensity, the signals in the low field aromatic region 143.77-143.89, 142.80-143.26 and $\approx 133$ ppm are ascribed to C-b and two ipso carbons $\mathrm{C}-\mathrm{h}$, and $\mathrm{C}-\mathrm{i}$ respectively in the benzimidazole moiety. ${ }^{13} \mathrm{C} \mathrm{NMR}$ assignments for the ring substituents and aromatic carbons were made by taking into account their substituent and electronic effects. In the case of para-fluoro substituted derivatives $\mathbf{2 4}$ and 25, phenyl carbons signal were split due to coupling with ${ }^{19} \mathrm{~F}$.

\section{Mass spectral analysis}

A proposed general fragmentation scheme for the target compounds with relatively abundant ions is presented in Figure 4 while the mass spectral data for the selected ions with their relative intensity are given in Table S1 [The mass spectral data (Table S1) and complete mass fragmentation pattern for compounds 21-26, 28 and $\mathbf{3 0}$ are given as Figures S3-S10 respectively in the supplementary files]. The mode of cleavages in all the compounds seems to be more or less common with slight difference among symmetrical (23, 25, 27, 29 and 30) and unsymmetrical $(\mathbf{2 1}, \mathbf{2 2}, \mathbf{2 4}, \mathbf{2 6}$ and 28) systems. All the compounds gave molecular ion-radical with appreciable abundance except chlorine and bromine bearing derivatives 26-29 (where the relative abundance is minimum). 


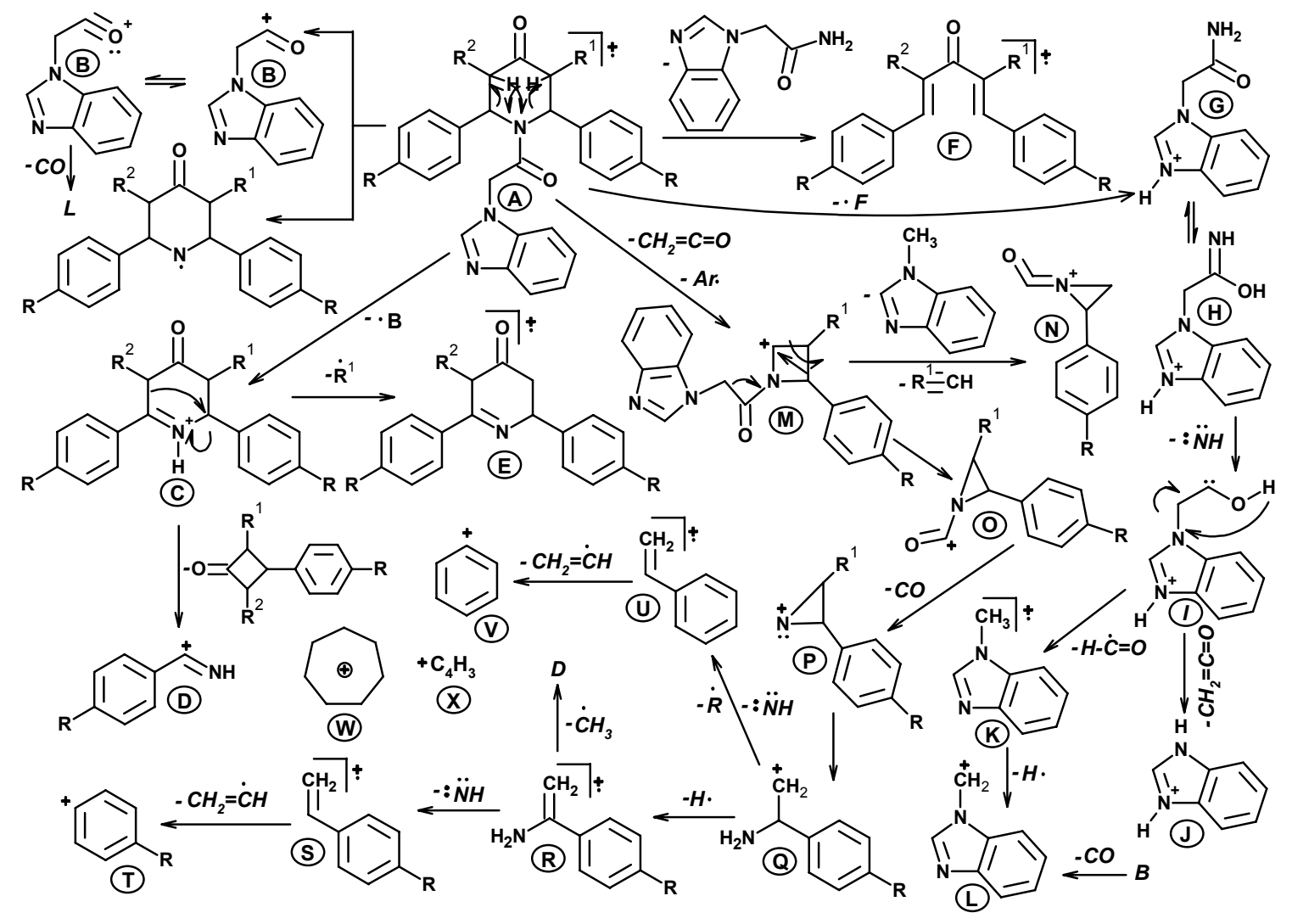

Figure 4. General mass spectral fragmentation pattern for 21-30.

In 24-29, isotope peaks characteristic for the presence of two halogen atoms were also been found in their respective mass spectra with least intensity. A close survey of the molecular masses of fragmented ions $\mathrm{B}$ and $\mathrm{C}$ revealed that amide $\mathrm{N}-\mathrm{C}=\mathrm{O}$ cleavage is prominent and is expected to occur in two different ways i.e., in one way, molecular ion A fragments to give a piperidone radical and resonance stabilized cation $\mathrm{B}$, which upon elimination of neutral carbon monoxide furnishes cation $\mathrm{L}$ with $\mathrm{m} / z$ 131. The ion $\mathrm{L}$ with $100 \%$ intensity served as base peak in 25-29 (refer Table S1). Alternatively, through the loss of radical B, ion $\mathrm{C}$ could be obtained which upon elimination of neutral 2,4-dialkyl-3-arylcyclobutanone and an alkyl radical gives two different ions $\mathrm{D}$ and $\mathrm{E}$. Formation of ion $\mathrm{D}$ is common in all the cases whereas ion $\mathrm{E}$ is relevant to unsubstituted phenyl bearing compounds 21-23. Similarly, in symmetrical analogues (except 29), piperidone $\mathrm{N}-\mathrm{C}$ bond cleavage is accompanied by the migration of adjacent methine protons thereby furnished dienone ion-radical $\mathrm{F}$ through the expulsion of neutral benzimidazole acetamide. Further, the common peak at $m / z 176$ in all cases can be attributed to cation G formed through the loss of dienone radical (.F) as outlined in Figure 4. We propose that fragmented ions $\mathrm{J}, \mathrm{K}$ and $\mathrm{L}$ are generated from cation $\mathrm{G}$ through the elimination of nitrene, enone and formyl radical as shown in Figure 4. The ion K with $m / z 132$ is the base peak in 21-23 as it posseses highest intensity (100\%) in their mass spectra. The observed significantly intense peaks with $\mathrm{m} / \mathrm{z}$ 
at 132 and 131 reveal that $N$-methylbenzimidazole radical-ion $\mathrm{K}$ and its cation $\mathrm{L}$ respectively are prominent in both unsubstituted and substituted phenyl-bearing compounds.

In the case of unsymmetrical systems, elimination of neutral enone and aryl radical from the molecular ion likely afforded cation $\mathrm{M}$, which, further fragments in two different modes to furnish ions $\mathrm{N}$ and $\mathrm{O}$. Similarly, the ion $\mathrm{O}$ undergoes a series of elimination process as indicated in Figure 4 to generate ions $\mathrm{P}-\mathrm{V}$. Ion $\mathrm{P}$ obtained from $\mathrm{O}$ through the loss of carbon monoxide is the most intense peak (base peak) in $\mathbf{2 4}$ and 30. The formation of tropylium cation is uncommon in the case of halogen-substituted phenyl-bearing compounds 24-29 except 27, but, the ions $\mathrm{U}, \mathrm{V}$ and $\mathrm{X}$ were observed in all cases.

\section{Conformational analysis and dynamic NMR studies}

The derived vicinal and geminal coupling constant values of compounds 21-30 are given in Table 1 along with the corresponding chloroacetyl intermediates ${ }^{3} \mathbf{1 1 - 2 0}$. An examination of the vicinal coupling constant values of the symmetrically substituted derivatives $(\mathbf{2 3}, \mathbf{2 5}, \mathbf{2 7}, 29$ and 30) reveal that the magnitude of ${ }^{3} J_{2 \mathrm{a}, 3 \mathrm{a}}$ and ${ }^{3} J_{5 \mathrm{a}, 6 \mathrm{a}}$ are closer to the corresponding precedent member and hence may adopt similar half boat conformations a and $\mathbf{b}$ in equilibrium (Figure 5). Replacement of one of the methyl groups (i.e., at C-5) by hydrogen (compounds 21, 24, 26 and 28) increased the magnitude of ${ }^{3} J_{2 \mathrm{a}, 3 \mathrm{a}}$ and decreased ${ }^{3} J_{5 \mathrm{a}, 6 \mathrm{a}}$ similar to 11, 14, 16 and 18. This is also clearly reflected in the small shielding of $\mathrm{H}-2$ and deshielding of H-6 protons. It suggests that the ring may be slightly puckered about $\mathrm{C}(2)-\mathrm{C}(3)$ and $\mathrm{C}(5)-\mathrm{C}(6)$ and expected to exists in equilibrium between conformations $\mathbf{a}$ and $\mathbf{b}$ as shown in Figure 6 . In the case of 22 with ethyl functionality at $\mathrm{C}-3$, the magnitude of vicinal coupling constants and shielding and deshielding of $\mathrm{H}-2 / \mathrm{H}-6$ protons are reversed as in 12. Therefore, in 22, the ring may be puckering about $\mathrm{C}(2)-\mathrm{C}(3)$ thereby adopts the twisted conformations $\mathbf{a}$ and $\mathbf{b}$ as shown in Figure 7. The proposed conformations of the compounds are presumed to exist in the solution state.
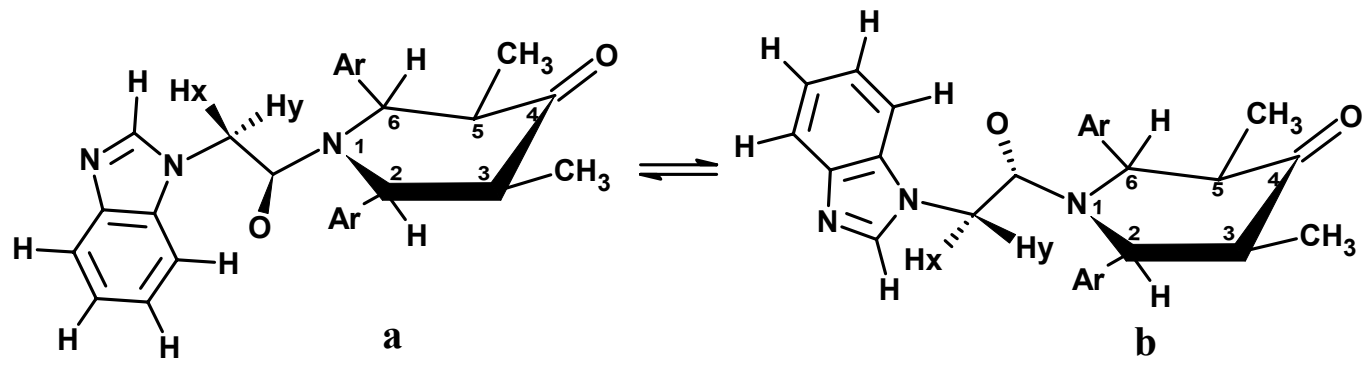

Figure 5. Conformations of compounds 23, 25, 27, 29 and 30. 


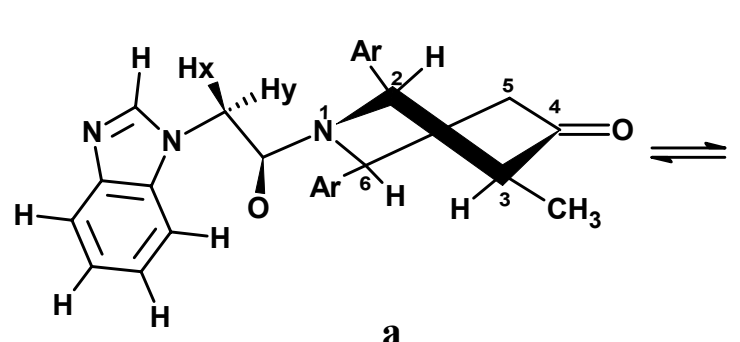

a

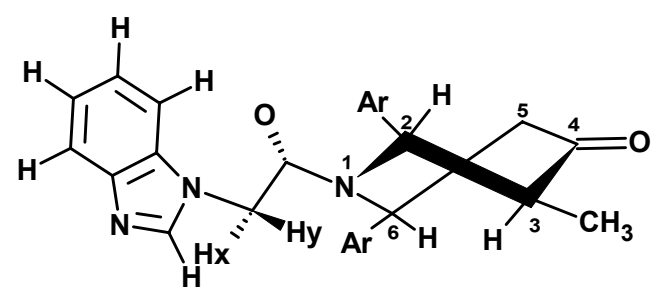

b

Figure 6. Conformations of compounds 21, 24, 26 and 28.
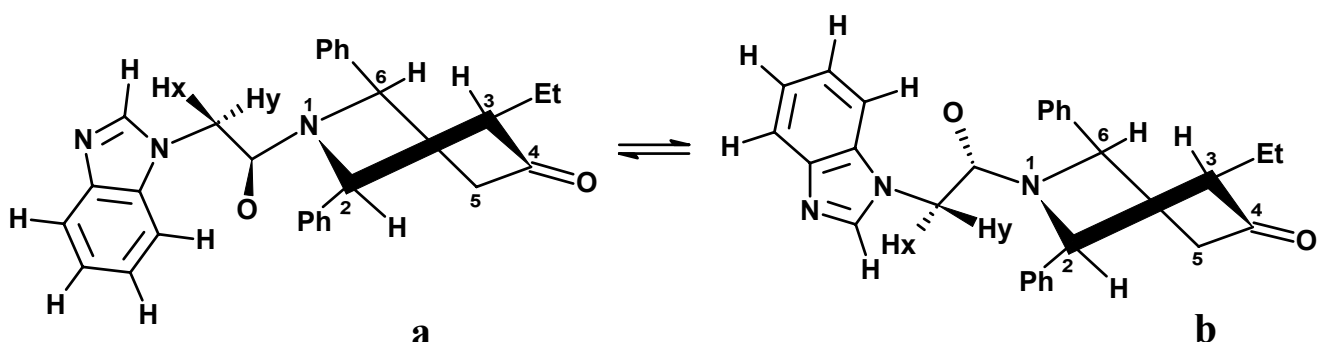

Figure 7. Conformations of compound 22.

However, slight changes in the vicinal coupling constants of $\mathrm{H}-3 \mathrm{a} / \mathrm{H}-5 \mathrm{a}$ and chemical shifts of $\mathrm{H}-2 / \mathrm{H}-6$ protons reveal that substitution of the bulkier benzimidazole moiety in place of chlorine exert some influence on the "in plane" nature of benzylic protons with amide carbonyl in the proposed conformations. Apparently, in the case of unsymmetrically substituted compounds (except 22) ${ }^{3} J_{3 \mathrm{a}, 2 \mathrm{a}}$ is increased and ${ }^{3} J_{5 \mathrm{a}, 6 \mathrm{a}}$ is decreased. Consequently, the H-6 proton was deshielded considerably compared to the chloroacetyl derivatives by its better in-plane nature whereas for $\mathrm{H}-2$, the reverse is true.

Inspection of the nature of the signals in both ${ }^{1} \mathrm{H}$ and ${ }^{13} \mathrm{C}$ NMR raises two questions:

(1) Which of the dynamic process is responsible for the broadening of benzylic protons signal in 21-30? i.e., is it due to ring flipping or ring reversal of the piperidone moiety or by hindered rotation about $\mathrm{N}-\mathrm{C}=\mathrm{O}$ bond?

(2) Which of the two different orientations are taken up by the introduced 2-(1H-benzimidazol-1yl)acetyl system? i.e., is it a coplanar or perpendicular orientation?

Here, we explored the answers for the above questions with evidence through temperaturedependent NMR spectra recorded for one of the symmetrically substituted compounds (29) from the target molecules at seven different temperatures from 293 to $218 \mathrm{~K}$ (from +20 to $-55^{\circ} \mathrm{C}$ ) in $\mathrm{CDCl}_{3}$. The results obtained are illustrated in Figure 8. At high temperatures: say $323 \mathrm{~K}\left(50{ }^{\circ} \mathrm{C}\right)$ and $303 \mathrm{~K}\left(30{ }^{\circ} \mathrm{C}\right)$, the signal due to the benzylic protons in 29 was not resolved into the anticipated multiplicity and remained similar to the one observed at 293K. Hence, the spectra at those high temperatures are not included in Figure 8. 


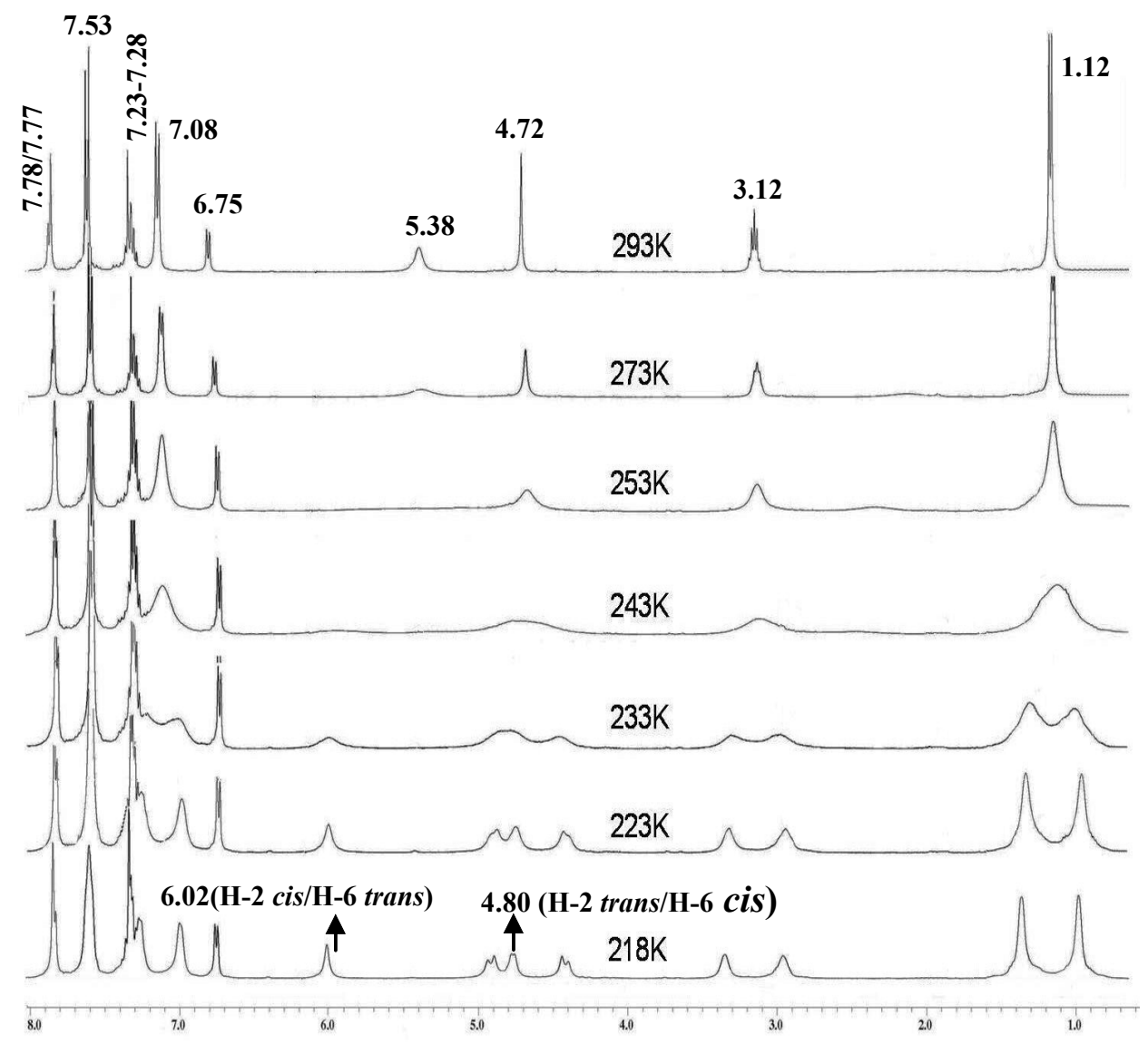

Figure 8. Temperature-dependent NMR spectra of compound 29.

To compare the dynamic NMR results of $\mathbf{2 9}$, we have also recorded temperature dependent NMR for one of the intermediate compounds $\mathbf{2 0}$ and this is displayed in Figure 9. It is very clear from Figure 8 that gradual cooling of the system has a significant effect on the nature of signals. In 29, signals due to benzylic (H-2/H-6), methyl (at C-3/ C-5), methine (H-3a and H-5a) and phenyl ortho protons (at C-2"/C-6") underwent exchange process at $253 \mathrm{~K}\left(-20^{\circ} \mathrm{C}\right.$ - coalescence temperature) as evidenced by their signal broadening. But, close to this slow exchange limit, signals due to acetyl methylene protons and phenyl meta protons (C-2"'/C-6") remain unaffected. However, at $243 \mathrm{~K}\left(-30^{\circ} \mathrm{C}\right)$ and $233 \mathrm{~K}\left(-40^{\circ} \mathrm{C}\right)$ respectively, they had also begun to take part in an exchange process. In the case of 20 (Figure 9), the situation is different at the above mentioned temperatures observed for exchange process i.e., the coalescence temperature for the piperidone ring protons signal appeared $20^{\circ} \mathrm{C}$ higher than those observed for $\mathbf{2 9}$. The broadening of signals could not be correlated to nitrogen inversion and ring reversal or flipping because the former is expected to be very fast and to be observable in the case of nitrogen heterocycles ${ }^{19}$ while ring flipping or reversal barriers for the same type of compounds were found to be greatly lower. ${ }^{20}$ 


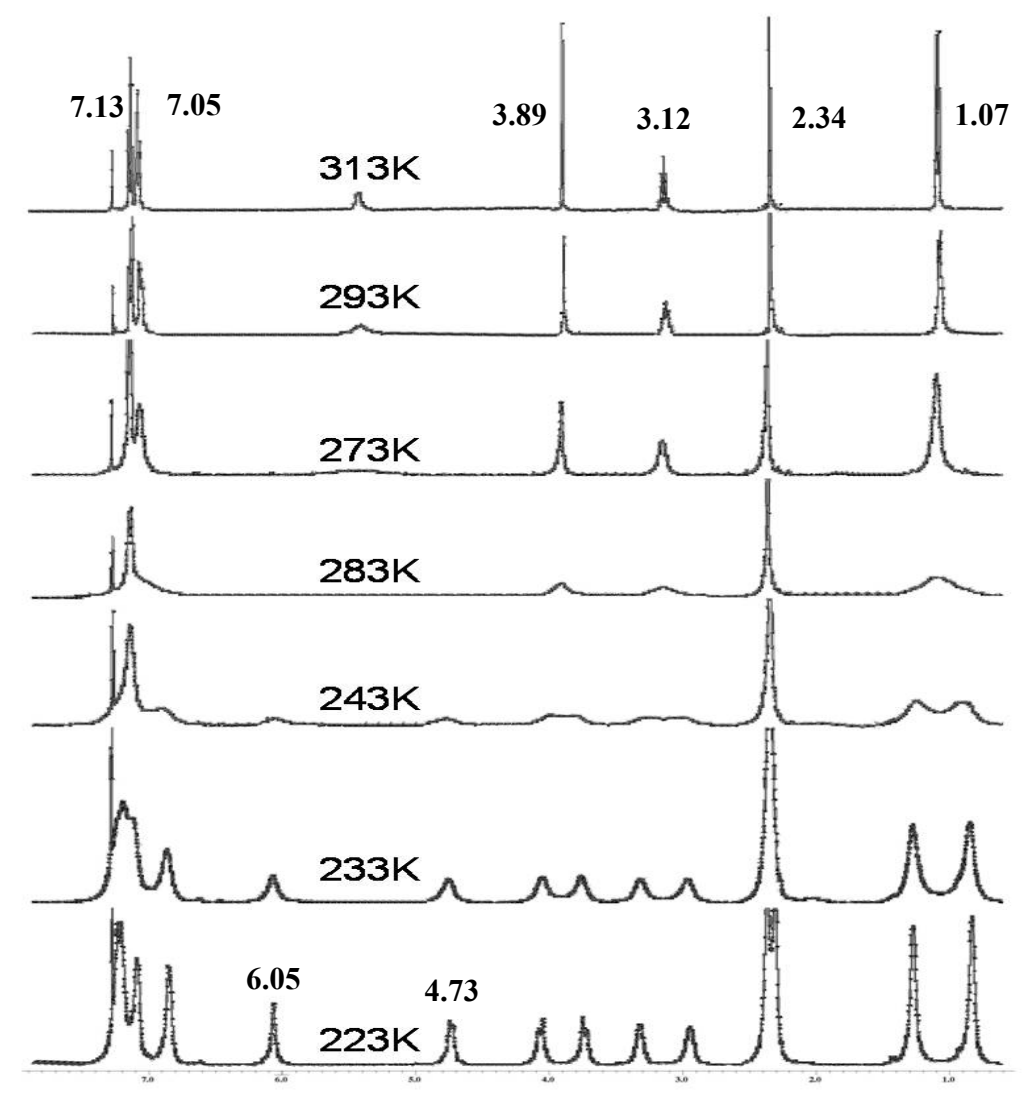

Figure 9. Temperature-dependent NMR spectra of compound $\mathbf{2 0 .}$

Therefore these two possibilities are neglected as they are expected to be too small to be observed in dynamic NMR. ${ }^{19}$ Thus, the only possibility for this signal broadening at ambient and at low temperatures should be due to the existence of hindered rotation about $\mathrm{N}-\mathrm{C}=\mathrm{O}$ bond as it attains partial double bond character by nitrogen lone pair delocalization with the carbonyl group (Scheme 2). The driving force for the mesomeric withdrawal of charge is attributed to the high electronegativity of oxygen which pulls the electrons from nitrogen thereby shortens the $\mathrm{C}-\mathrm{N}$ bond length. The existence of restricted rotation in these molecules is also confirmed by a remarkable shielding of the benzylic carbons (C-2/C-6) and a deshielding of the corresponding protons $(\mathrm{H}-2 / \mathrm{H}-6)$ resonances.

Hence, two rotomers 1 and 2 (Scheme 2) may likely result from slow cis-to-trans isomerization (by restricted rotation). However, we did not find a set of distinct signals corresponding to both the rotomers in 21-30 at room temperature. This indicates that rotation about $\mathrm{N}-\mathrm{C}=\mathrm{O}$ bond is sufficiently fast on the NMR time-scale at ambient temperature and produced an average NMR for both cis and trans isomers. This analogy is also confirmed through inspection of the NMR signals in Figures 8 and 9. Here, at temperatures above 293K $\left(-20{ }^{\circ} \mathrm{C}\right)$ for 20 and $303 \mathrm{~K}\left(-30^{\circ} \mathrm{C}\right)$ for 29 , we observed an average NMR through fast interconversion while below these temperatures, the signals were broadened, coalesce and split 
into two set of signals (except for protons at C-2"'/C-6"'in 29) with perfectly equal intensity by slow interconversion between two rotomers 1 and 2. Of the set of benzylic proton signals at $218 \mathrm{~K}$ in 29 , the doublet at $4.80 \mathrm{ppm}$ with $J=8.79 \mathrm{~Hz}$ is due to $\mathrm{H}-2$ trans/H-6 cis, while the singlet at $6.02 \mathrm{ppm}$ corresponds to $\mathrm{H}-2$ cis/H-6 trans of both the rotomers 1 and $2 .^{21}$ Similarly, the two doublets at $4.46(J=15.82 \mathrm{~Hz})$ and $4.95 \mathrm{ppm}(J=16.69 \mathrm{~Hz})$ are attributed to $\mathrm{Hx}$ and Hy of the acetyl methylene protons whereas the singlets at $2.97 / 3.35 \mathrm{ppm}$ and $0.97 / 1.34 \mathrm{ppm}$ are pertinent to $\mathrm{C}-3 / \mathrm{C}-5$ methine protons and methyl protons at C-3/C-5 respectively of cis and trans rotomers. The intensity and anisochronous nature of acetyl methylene and piperidone ring protons clearly demonstrates that cis and trans isomers (rotomers 1 and 2) exist in exactly a 1:1 ratio at low temperatures. Another interesting observation from the dynamic NMR studies is the broadening of the phenyl protons signal at lower temperatures. Although free rotation of phenyl groups is well known, in $\mathbf{2 0}$ and $\mathbf{2 9}$, the said groups undergo restricted rotation due to steric hindrance by both methyl groups at $\mathrm{C}-3 / \mathrm{C}-5$ and amide carbonyl group in the stable conformation.

The orientation of the acyl substituent in the case of $\mathrm{N}$-acyl derivatives of 2,6-disubstituted and unsubstituted piperidines system has been established by Lunazzi et al. $^{22}$ through NMR studies. They stated that if the substituent at nitrogen is dispositioned perpendicular to the average plane of the piperidine ring, C-2/C-6 and C-3/C-5 carbons and their attached protons become isochronous. On the other hand, if it is in a coplanar orientation, then these carbons and protons become anisochronous. They also stated that a perpendicular orientation does not bring about broadening of signal. These analogies are fruitful in our case also, as the ring protons become anisochronous and broadened while lowering the NMR operating temperature (Figures 8 and 9).

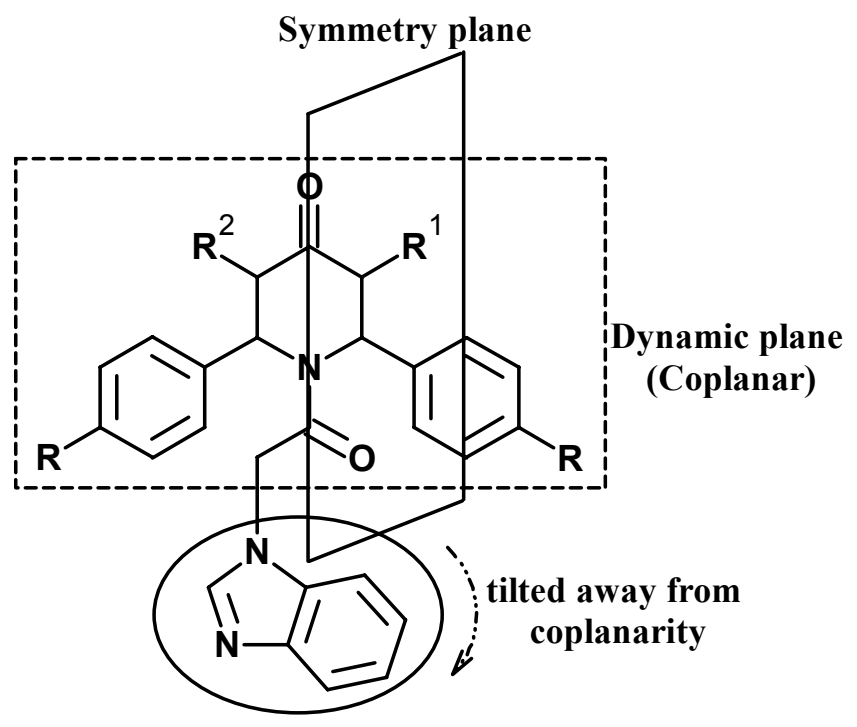

Figure 10. Coplanar representation of amide group. 
Thus, dynamic NMR results, coupling constant values and deshielding of benzylic protons strongly evidenced the coplanar orientation of the substituent at nitrogen in 21-30 with a dynamically averaged plane of the piperidone ring system as shown in Figure 10. This is also supported by the X-ray diffraction study of compound $\mathbf{2 0}$ described in the next section.

Moreover, a striking observation from Figure 8 is that, restricted rotation has exchanged only some of the signals: it affected only $-\mathrm{COCH}_{2}$ and piperidone ring protons signals, and it did not exert any effect on signals assigned to groups whose environment is unchanged by hindered rotation, i.e., those of the benzimidazole ring. Though the signals due to protons of this heterocyclic substituent are not affected in its dynamic NMR, there could be no possibility for geared rotation ${ }^{23}$ because the benzimidazole aromatic system is involved in conjugation with the amide carbonyl function since it is separated by an aliphatic methylene group. Further, if this bulkier system were coplanar with the amide carbonyl plane, there would be a severe allylic strain with the phenyl groups of the piperidone system, besides its steric influence for the hindered $\mathrm{N}-\mathrm{C}=\mathrm{O}$ rotation at ambient temperature. Thus, despite the coplanarity of the acetyl substituent (i.e., $\mathrm{N}-\underline{\mathrm{COCH}}_{2}$ ), the benzimidazole framework most likely is tilted away from coplanarity. This consideration is also supported by the observed shielding of the benizimidazole ring protons resonance in this system compared to its actual resonance. ${ }^{24}$

The above said observations are also supported by the increased magnitude of coupling constant values (about 4-5 Hz) of $\mathrm{Hx}$ and Hy protons from their chloroacetyl derivatives 11-20. Thus, the introduced bulkier benzimidazole system tends to be away from the coplanarity.

\section{X-Ray structural analysis}

NMR spectral investigations including dynamic studies have demonstrated similar conformations for both the intermediates and the target compounds in solution state. However we felt that it was worthwhile to study the crystal structure of a typical compound, 20 (Figure 11) to substantiate the coplanarity of the acyl group in 21-30. Earlier, the ideal conformation of r-2,c-6-bis(4-fluorophenyl)-t-3,t-5-dimethylpiperidin-4-one, ${ }^{25}$ in the solid state was found to be same as that reported in the liquid state i.e., a rigid chair conformation. But chloroacetylation of 2,6-diarylpiperidin-4-ones revealed changes in the conformation of these compounds in solution state from consideration of the significant changes in their coupling constant values. To assess the change in the conformation upon chloroacetylation more precisely, an X-ray diffraction study was carried out on $\mathbf{2 0}$ and the crystal data and structural refinements are given in Table S2 (supplementary data). In solution, both the chloroacetylated and their corresponding (1H-benzimidazol-1-yl)acetyl derivatives exist in an equilibrium between the conformations a and $\mathbf{b}$ (Figures 5-7). 


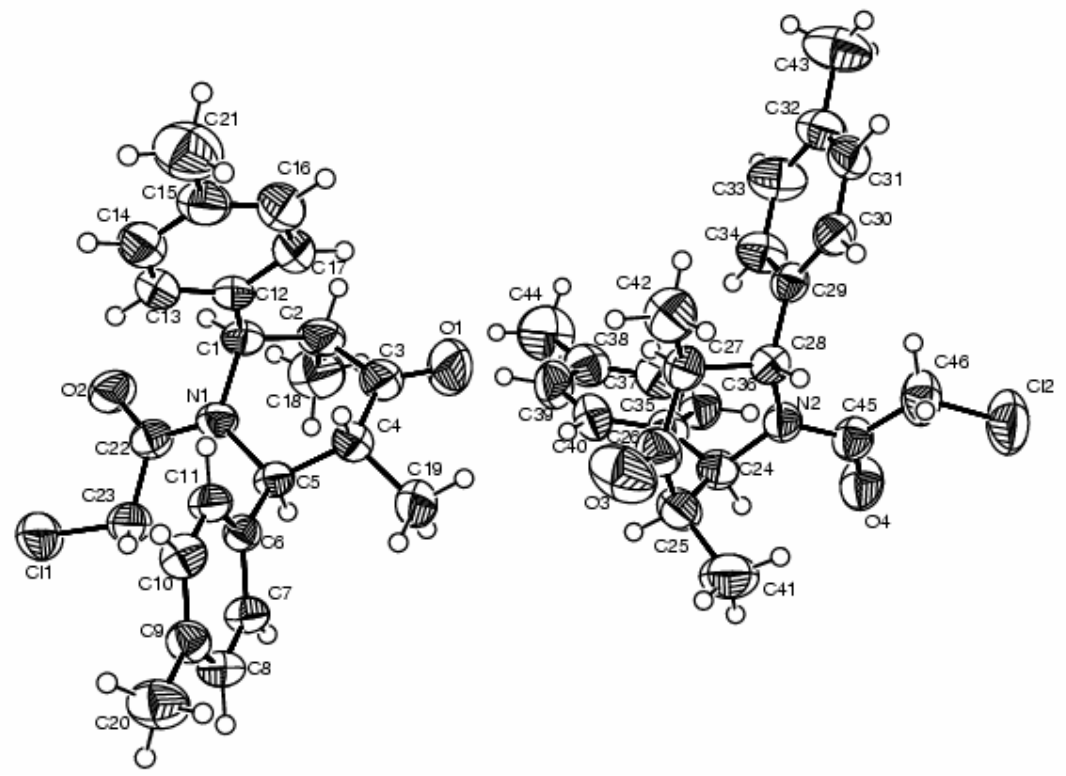

Figure 11. ORTEP of compound 20. (The asymmetric unit of the compound 20 contains two crystallographically independent molecules).

However, X-ray diffraction study of compound $\mathbf{2 0}$ clearly indicates that the piperidone moiety is twisted about $\mathrm{C}(24)-\mathrm{N}(2)-\mathrm{C}(28)$ and adopts a conformation which is intermediate between the sofa and half-chair conformations. Further, the phenyl group at $\mathrm{C}(2)[\mathrm{C}(24)$ in Figure 11] is oriented axially while the other at $\mathrm{C}(6)[\mathrm{C}(28)$ in Figure 11] oriented equatorially. Coplanarity of the $\mathrm{N}-\mathrm{COCH}_{2}$ function is confirmed by the observed bond lengths $[\mathrm{C}(24)-\mathrm{N}(2)=$ $1.485 \AA ; \mathrm{C}(28)-\mathrm{N}(2)=1.485 \AA ; \mathrm{C}(45)-\mathrm{N}(2)=1.348 \AA ; \mathrm{C}(45)-\mathrm{O}(4)=1.224 \AA ; \mathrm{C}(45)-\mathrm{C}(46)=$ $1.510 \AA$-Table 3] where $\mathrm{C}(45)-\mathrm{N}(2)$ bond length is decreased compared to $\mathrm{C}(24)-\mathrm{N}(2) / \mathrm{C}(28)-$ $\mathrm{N}(2)$ and confirms the effective conjugation between lone pair of nitrogen with carbonyl group. Moreover, the noted bond angles $\left[\mathrm{C}(24)-\mathrm{N}(2)-\mathrm{C}(28)=119.2^{\circ} ; \mathrm{C}(45)-\mathrm{N}(2)-\mathrm{C}(24)=117.2^{\circ}\right.$; $\mathrm{C}(45)-\mathrm{N}(2)-\mathrm{C}(28)=122.5^{\circ} ; \mathrm{N}(2)-\mathrm{C}(45)-\mathrm{C}(46)=116.6^{\circ}$ - Table 3] and torsional angles (Table 3 ) also confirm this coplanarity. Since the coupling constant values and chemical shift values of the 1-[2-(1H-benzimidazol-1-yl)acetyl]-2,6-diarylpiperidin-4-ones did not change significantly from their corresponding chloroacetyl derivatives, these compounds are also expected to adopt the similar conformations as noted in the X-ray diffraction study.

\section{Antimicrobial activity}

Antimicrobial activity of the synthesized compounds was examined against Staphylococcus aureus, Bacillus subtilis, Salmonella typhi, Aspergillus niger, Aspergillus flavus and Candida albicans. Ciprofloxacin and Amphotericin B were used as standard drugs for bacterial and fungal strains respectively. 
Table 3. Important bond lengths $[\AA]$, bond angles [deg.] and torsion angles [deg.] of $\mathbf{2 0}$

\begin{tabular}{cccc}
\hline \multirow{2}{*}{ Bond } & $\begin{array}{c}\text { Bond length / } \\
\text { Bond angle }\end{array}$ & \multicolumn{1}{c}{ Bond } & Torsion angle \\
\hline $\mathrm{C}(24)-\mathrm{N}(2)$ & $1.485(3) /-$ & $\mathrm{N}(2)-\mathrm{C}(24)-\mathrm{C}(25)-\mathrm{C}(26)$ & $50.6(3)$ \\
$\mathrm{C}(28)-\mathrm{N}(2)$ & $1.485(3) /-$ & $\mathrm{C}(26)-\mathrm{C}(27)-\mathrm{C}(28)-\mathrm{N}(2)$ & $46.6(3)$ \\
$\mathrm{C}(45)-\mathrm{N}(2)$ & $1.348(3) /-$ & $\mathrm{N}(2)-\mathrm{C}(28)-\mathrm{C}(29)-\mathrm{C}(30)$ & $-134.1(2)$ \\
$\mathrm{C}(45)-\mathrm{O}(4)$ & $1.224(3) /-$ & $\mathrm{N}(2)-\mathrm{C}(28)-\mathrm{C}(29)-\mathrm{C}(34)$ & $50.2(3)$ \\
$\mathrm{C}(45)-\mathrm{C}(46)$ & $1.510(4) /-$ & $\mathrm{N}(2)-\mathrm{C}(24)-\mathrm{C}(35)-\mathrm{C}(40)$ & $-121.2(3)$ \\
$\mathrm{C}(45)-\mathrm{C}(46)-\mathrm{Cl}(2)$ & $-/ 113.0(2)$ & $\mathrm{N}(2)-\mathrm{C}(24)-\mathrm{C}(35)-\mathrm{C}(36)$ & $61.1(3)$ \\
$\mathrm{O}(4)-\mathrm{C}(45)-\mathrm{N}(2)$ & $-/ 122.7(2)$ & $\mathrm{N}(2)-\mathrm{C}(45)-\mathrm{C}(46)-\mathrm{Cl}(2)$ & $-178.7(2)$ \\
$\mathrm{N}(2)-\mathrm{C}(45)-\mathrm{C}(46)$ & $-/ 116.6(2)$ & $\mathrm{O}(4)-\mathrm{C}(45)-\mathrm{N}(2)-\mathrm{C}(24)$ & $9.0(4)$ \\
$\mathrm{N}(2)-\mathrm{C}(28)-\mathrm{C}(29)$ & $-/ 113.4(2)$ & $\mathrm{C}(46)-\mathrm{C}(45)-\mathrm{N}(2)-\mathrm{C}(24)$ & $-170.3(2)$ \\
$\mathrm{N}(2)-\mathrm{C}(28)-\mathrm{C}(27)$ & $-/ 110.78(19)$ & $\mathrm{O}(4)-\mathrm{C}(45)-\mathrm{N}(2)-\mathrm{C}(28)$ & $-179.7(3)$ \\
$\mathrm{N}(2)-\mathrm{C}(24)-\mathrm{C}(25)$ & $-/ 108.8(2)$ & $\mathrm{C}(46)-\mathrm{C}(45)-\mathrm{N}(2)-\mathrm{C}(28)$ & $1.0(4)$ \\
$\mathrm{N}(2)-\mathrm{C}(24)-\mathrm{C}(35)$ & $-/ 113.4(2)$ & $\mathrm{C}(25)-\mathrm{C}(24)-\mathrm{N}(2)-\mathrm{C}(45)$ & $120.2(3)$ \\
$\mathrm{C}(45)-\mathrm{N}(2)-\mathrm{C}(24)$ & $-/ 117.7(2)$ & $\mathrm{C}(25)-\mathrm{C}(24)-\mathrm{N}(2)-\mathrm{C}(28)$ & $-51.4(3)$ \\
$\mathrm{C}(45)-\mathrm{N}(2)-\mathrm{C}(28)$ & $-/ 122.5(2)$ & $\mathrm{C}(27)-\mathrm{C}(28)-\mathrm{N}(2)-\mathrm{C}(45)$ & $-169.2(2)$ \\
$\mathrm{C}(24)-\mathrm{N}(2)-\mathrm{C}(28)$ & $-/ 119.22(19)$ & $\mathrm{C}(29)-\mathrm{C}(28)-\mathrm{N}(2)-\mathrm{C}(24)$ & $-122.2(2)$ \\
\hline
\end{tabular}

The observed zone of growth inhibition ( $\mathrm{mm}$ ) with activity index is given in Table 4. From this table, it is very clear that compounds $21\left(\mathrm{CH}_{3}\right.$ at $\left.\mathrm{C}-3\right)$ and $22\left(\mathrm{CH}_{2} \mathrm{CH}_{3}\right.$ at $\left.\mathrm{C}-3\right)$ without any substitution at the para position of the phenyl groups exerted poor activity whereas introduction of another methyl group at C-5 in $\mathbf{2 1}$ (Compound 23) produced excellent activity against the tested bacterial and fungal strains. Against $S$. aureus, compound $\mathbf{2 3}$ displayed almost equipotency with that of the standard drug used. But, substitution of an electron-withdrawing halogen atom at the para position of the phenyl moiety in $\mathbf{2 3}$ (Compounds 25, 27 and 29) did not promote the activity appreciably except $\mathbf{2 5}$ against $A$. flavus. However, these substitutions in $\mathbf{2 1}$ showed significant improvement in the inhibitory activity and particularly compound $\mathbf{2 4}$ against $S$. typhi exhibited marked growth inhibition. Thus, the antimicrobial activities of halogensubstituted compounds falls in the following order fluorine $>$ chlorine $>$ bromine as shown in Table 4. Therefore, the electron-withdrawing power of halogen plays a crucial role in the inhibitory potency of this class of compounds. Besides this, substitution of electron-donating methyl group instead of halogen in $\mathbf{2 3}$ (compound 30) also failed to improve the inhibition potency. This study clearly envisages that substitution of electron withdrawing or releasing substituents at the phenyl groups has no impact on the antimicrobial potency of 3,5-dimethyl derivatives. 
Table 4. Antimicrobial activities of novel compounds 21-30 against selected microbial strains with activity index

\begin{tabular}{|c|c|c|c|c|c|c|c|c|c|}
\hline \multirow{3}{*}{$\begin{array}{l}\vec{\Xi} \\
\overline{0} \\
\text { ڤ్ } \\
\text { ठ }\end{array}$} & \multirow{3}{*}{$\mathrm{R}_{1}$} & \multirow{3}{*}{$\mathrm{R}_{2}$} & \multirow{3}{*}{$\mathrm{R}$} & \multicolumn{6}{|c|}{ Zone of diameter of inhibition $(\mathrm{mm})^{\#}$} \\
\hline & & & & \multicolumn{3}{|c|}{$\begin{array}{l}\text { Antibacterial activity } \\
\quad \text { (in } 100 \mu \mathrm{g} / \mathrm{mL} \text { ) }\end{array}$} & \multicolumn{3}{|c|}{$\begin{array}{l}\text { Antifungal activity } \\
\text { (in } 100 \mu \mathrm{g} / \mathrm{mL} \text { ) }\end{array}$} \\
\hline & & & & $\begin{array}{l}\text { S. aureus } \\
\text { (A.I)* }\end{array}$ & $\begin{array}{c}\text { B. } \\
\text { subtilis } \\
\text { (A.I)* }\end{array}$ & $\begin{array}{c}S . \\
\text { typhi } \\
\text { (A.I)* }\end{array}$ & $\begin{array}{c}\text { A. } \\
\text { niger } \\
\text { (A.I)* }\end{array}$ & $\begin{array}{l}\text { A. flavus } \\
\text { (A.I)* }\end{array}$ & $\begin{array}{c}C . \\
\text { albicans } \\
\text { (A.I)* }\end{array}$ \\
\hline 21 & $\mathrm{Me}$ & $\mathrm{H}$ & $\mathrm{H}$ & $\begin{array}{c}08.2 \\
(0.29)\end{array}$ & $\begin{array}{c}10.0 \\
(0.33)\end{array}$ & $\begin{array}{c}07.2 \\
(0.23)\end{array}$ & $06.3(0.25)$ & $\begin{array}{c}09.0 \\
(0.39)\end{array}$ & $\begin{array}{c}10.1 \\
(0.39)\end{array}$ \\
\hline 22 & Et & $\mathrm{H}$ & $\mathrm{H}$ & $\begin{array}{c}05.3 \\
(0.19)\end{array}$ & $\begin{array}{c}11.1 \\
(0.37)\end{array}$ & $\begin{array}{c}09.1 \\
(0.29)\end{array}$ & $08.1(0.32)$ & $\begin{array}{c}06.2 \\
(0.27)\end{array}$ & $\begin{array}{c}05.0 \\
(0.19)\end{array}$ \\
\hline 23 & $\mathrm{Me}$ & $\mathrm{Me}$ & $\mathrm{H}$ & $\begin{array}{c}26.1 \\
(0.93)\end{array}$ & $\begin{array}{c}22.3 \\
(0.74)\end{array}$ & $\begin{array}{c}25.0 \\
(0.80)\end{array}$ & $19.5(0.77)$ & $\begin{array}{c}18.0 \\
(0.78)\end{array}$ & $\begin{array}{c}21.2 \\
(0.81)\end{array}$ \\
\hline 24 & $\mathrm{Me}$ & $\mathrm{H}$ & $\mathrm{F}$ & $\begin{array}{c}22.0 \\
(0.79)\end{array}$ & $\begin{array}{c}19.1 \\
(0.63)\end{array}$ & $\begin{array}{c}26.1 \\
(0.84)\end{array}$ & $17.2(0.68)$ & $\begin{array}{c}19.2 \\
(0.83)\end{array}$ & $\begin{array}{c}20.0 \\
(0.77)\end{array}$ \\
\hline 25 & $\mathrm{Me}$ & $\mathrm{Me}$ & $\mathrm{F}$ & $\begin{array}{c}21.0 \\
(0.75)\end{array}$ & $\begin{array}{c}20.2 \\
(0.67)\end{array}$ & $\begin{array}{c}14.0 \\
(0.45)\end{array}$ & $15.1(0.23)$ & $\begin{array}{c}20.0 \\
(0.87)\end{array}$ & $\begin{array}{c}21.0 \\
(0.81)\end{array}$ \\
\hline 26 & $\mathrm{Me}$ & $\mathrm{H}$ & $\mathrm{Cl}$ & $\begin{array}{c}10.3 \\
(0.37)\end{array}$ & $\begin{array}{c}12.2 \\
(0.40)\end{array}$ & $\begin{array}{c}16.2 \\
(0.52)\end{array}$ & $10.0(0.60)$ & $\begin{array}{c}16.3 \\
(0.71)\end{array}$ & $\begin{array}{c}18.3 \\
(0.70)\end{array}$ \\
\hline 27 & $\mathrm{Me}$ & $\mathrm{Me}$ & $\mathrm{Cl}$ & $\begin{array}{c}15.1 \\
(0.54)\end{array}$ & $\begin{array}{c}07.0 \\
(0.23)\end{array}$ & $\begin{array}{c}13.1 \\
(0.42)\end{array}$ & $08.0(0.32)$ & $\begin{array}{c}17.0 \\
(0.74)\end{array}$ & $\begin{array}{c}15.2 \\
(0.58)\end{array}$ \\
\hline 28 & $\mathrm{Me}$ & $\mathrm{H}$ & $\mathrm{Br}$ & $\begin{array}{c}14.4 \\
(0.51)\end{array}$ & $\begin{array}{c}06.3 \\
(0.21)\end{array}$ & $\begin{array}{c}11.5 \\
(0.37)\end{array}$ & $07.3(0.29)$ & $\begin{array}{c}15.1 \\
(0.60)\end{array}$ & $\begin{array}{c}09.5 \\
(0.36)\end{array}$ \\
\hline 29 & $\mathrm{Me}$ & $\mathrm{Me}$ & $\mathrm{Br}$ & $\begin{array}{c}11.2 \\
(0.40)\end{array}$ & $\begin{array}{c}16.1 \\
(0.53)\end{array}$ & $\begin{array}{c}09.5 \\
(0.30)\end{array}$ & $10.5(0.42)$ & $\begin{array}{c}08.0 \\
(0.35)\end{array}$ & $\begin{array}{c}11.1 \\
(0.43)\end{array}$ \\
\hline 30 & $\mathrm{Me}$ & $\mathrm{Me}$ & $\mathrm{Me}$ & $\begin{array}{c}16.1 \\
(0.58)\end{array}$ & $\begin{array}{c}11.2 \\
(0.37)\end{array}$ & $\begin{array}{c}08.2 \\
(0.26)\end{array}$ & $13.1(0.52)$ & $\begin{array}{c}11.2 \\
(0.49)\end{array}$ & $\begin{array}{c}10.2 \\
(0.39)\end{array}$ \\
\hline $\begin{array}{c}\text { Cipro } \\
\text { f loxacin }\end{array}$ & & & & 28.0 & 30.3 & 31.2 & -- & -- & -- \\
\hline $\begin{array}{l}\text { Amphote } \\
\text { ricin B }\end{array}$ & & & & -- & -- & -- & 25.2 & 23.0 & 26.1 \\
\hline
\end{tabular}

\# The data represents the mean values of two replicates.

*A.I $=$ > Activity Index = Diameter of inhibition zone $(\mathrm{mm})$ in test sample/ Diameter of inhibition zone $(\mathrm{mm})$ in standard.

Hence, it is concluded that compound $\mathbf{2 3}$ among the symmetrically substituted compounds and 24 among the unsymmetrically substituted compounds registered an elevated inhibitory activity against both the tested bacterial and fungal strains while other compounds were found to be not effective against any of the strains selected for this study. We found in our earlier studies 
that substitution of acetyl derivatives in piperidone nitrogen ${ }^{2}$ produced more pronounced biological profiles than the corresponding $O$-alkyl derivatives. ${ }^{26}$ From this, we presumed that the change in conformation due to acetylation might have influenced the better biological responses. However, these preliminary observations suggested the need for elaborate study to find out the correlation between the stereochemistry and bioactivity. These are now in progress in our laboratory.

\section{Conclusions}

The dynamic, one- and two-dimensional NMR studies of 21-30 clearly revealed the existence of hindered rotation about $\mathrm{N}-\mathrm{C}=\mathrm{O}$ bond and its coplanarity with the dynamically averaged plane of the piperidone ring system. Also, at low temperatures, two rotomers (cis and trans) of symmetrically substituted analogues exist in a perfectly 1:1 ratio. Magnetic anisotropy plays a significant role in shielding the resonance of H-g and phenyl ortho protons as they lie above the plane of amide carbonyl function. Moreover, non-broadening of benzimidazole ring protons while lowering the temperature obviously predicts the deviation of this introduced moiety from coplanarity. Symmetrical and unsymmetrical sets of compounds exhibit a typical mode of fragmentation patterns. X-ray diffraction study of the intermediate compound $\mathbf{2 0}$ further confirms the coplanarity of the $\mathrm{N}$-acyl group and change in the piperidone ring conformation. Preliminary antimicrobial screening clearly indicates that substitution of halogens at the para position of the phenyl groups exerts better activity in 3-methyl derivatives whereas in the 3,5dimethyl derivatives, such substitution decreases the activity.

\section{Experimental Section}

General Procedures. The progress of the reactions and purity of the products were ascertained by performing TLC. Melting points were determined in Electrothermal-9100 (Japan) instrument and are uncorrected. All the NMR spectra were recorded on JEOL (Japan) JNM ECP-400 instrument operating at $400 \mathrm{MHz}$ for proton and $100.6 \mathrm{MHz}$ for completely proton decoupled

${ }^{13} \mathrm{C}$. $\mathrm{CDCl}_{3}$ was used as a solvent and in some cases, a drop of DMSO- $d_{6}$ was also added for solubility. The tubes used for recording NMR spectra are of $5 \mathrm{~mm}$ in diameter. The chemical shift values are reported in ppm (parts per million) relative to TMS and the spin multiplicities are indicated as s (singlet), bs (broad singlet), d (doublet), dd (double doublet), q (quintet) and $\mathrm{m}$ (multiplet). Coupling constant $(J)$ values are represented in $\mathrm{Hz}$ (Hertz). IR spectrum was recorded in FT-IR Perkin-Elmer Spectrum GX spectrophotometer and only noteworthy absorption levels (reciprocal centimeters) were taking into account. Mass spectra were recorded on a JEOL, JMS-700 instrument and microanalyses were performed on Heraeus Carlo Erba 1108 
CHN analyzer. Purification of the final compounds was done by silica gel (200-400 mesh-60A) column chromatography.

The synthetic pathway which furnished the target compounds is shown in Scheme 1. 2,6-Diarylpiperidin-4-ones 1-10 were prepared by the method of Noller and Baliah ${ }^{27}$ while their corresponding chloroacetyl derivatives (11-20) were prepared by adopting our earlier report. ${ }^{3}$

\section{General procedure for the synthesis of compounds 21-30}

The compounds were prepared by adopting the earlier method. ${ }^{9}$ A mixture of benzimidazole $(0.005 \mathrm{~mol})$ and $\mathrm{K}_{2} \mathrm{CO}_{3}(0.01 \mathrm{~mol})$ in $\mathrm{DMF}(10 \mathrm{~mL})$ were stirred at room temperature for 15 minutes. Later, a solution of the $N$-chloroacetyl-2,6-diarylpiperidin-4-one (0.005 mol) in DMF $(10 \mathrm{~mL})$ was added and the mixture stirred continuously for about 2-3 hours. After completion of the reaction, $\mathrm{K}_{2} \mathrm{CO}_{3}$ was filtered off and excess solvent was removed under reduced pressure. The residue was poured into crushed ice and extracted twice with ethyl acetate. The combined organic extracts were then washed well with ice water, brine and dried over sodium sulfate. Evaporation of the solvent under reduced pressure gave a crude mass, which upon purification over silica gel using methanol-chloroform (1:10) mixture as eluent afforded the products as a resinous mass. This upon trituration with DCM furnished the compound as spongy dirty white solid.

1-[2-(1H-Benzimidazol-1-yl)acetyl]-3-methyl-2,6-diphenylpiperidin-4-one (21). Yield = 81\%, m.p. 223-224 ${ }^{\circ} \mathrm{C} .{ }^{1} \mathrm{H}$ NMR (400 MHz, $\left.\mathrm{CDCl}_{3}\right)$ : 7.77 (d, 1H, $\left.J_{\mathrm{d}, \mathrm{e}}=7.72, \mathrm{H}-\mathrm{d}\right), 7.72$ (s, 1H, H-b), 7.42-7.34 (m, 6H, other aromatic protons), 7.30-7.19 (m, 2H, H-f/H-e), 7.17-7.16 (m, 4H, ortho protons), 6.74 (d, 1H, $\left.J_{\mathrm{g}, \mathrm{f}}=7.32, \mathrm{H}-\mathrm{g}\right), 6.04$ (bs [with mild splitting at the peak], 1H, H-6), 5.29 (bs, $1 \mathrm{H}, \mathrm{H}-2), 4.75\left(\mathrm{~d}, 1 \mathrm{H},{ }^{2} J_{\mathrm{Hx}, \mathrm{Hy}}=17.21,-\mathrm{COCH} H \mathrm{x}\right), 4.66\left(\mathrm{~d}, 1 \mathrm{H},{ }^{2} J_{\mathrm{Hy}, \mathrm{Hx}}=16.84,-\mathrm{COCH} H \mathrm{y}\right)$, $3.24\left(\mathrm{dd}, 1 \mathrm{H},{ }^{2} J_{5 \mathrm{a}, 5 \mathrm{e}}=18.31,{ }^{3} J_{5 \mathrm{a}, 6 \mathrm{a}}=5.49, \mathrm{H}-5 \mathrm{ax}\right), 3.11\left(\mathrm{q}, 1 \mathrm{H},{ }^{3} J_{3 \mathrm{a}, 2 \mathrm{a}}=7.08, \mathrm{H}-3 \mathrm{ax}\right), 2.86(\mathrm{dd}$, $\left.1 \mathrm{H},{ }^{2} J_{5 \mathrm{e}, 5 \mathrm{a}}=18.49,{ }^{3} J_{5 \mathrm{e}, 6 \mathrm{a}}=6.04, \mathrm{H}-5 \mathrm{eq}\right), 1.07\left(\mathrm{~d}, J_{\mathrm{Me}, \mathrm{H}}=6.59,3 \mathrm{H}, \mathrm{CH}_{3}\right.$ at C-3). ${ }^{13} \mathrm{C} \mathrm{NMR}(400$ $\mathrm{MHz}, \mathrm{CDCl}_{3} / \mathrm{DMSO}_{6}$ ): 208.18 (C-4), 168.79 (N-C=O), 143.81 (C-b), 143.03 (C-i), 140.83 (C6'), 140.63 (C-2'), 133.89 (C-h), 129.1-126.64 (aryl carbons), 122.91 (C-e), 122.03 (C-f), 120.15 (C-d), 108.86 (C-g), 62.24 (C-2), 53.73 (C-6), 46.90 (-COCH 2$), 46.13$ (C-3), 42.84 (C-5), 13.19 $\left(\mathrm{CH}_{3}\right.$ at C-3). Anal. cald. for $\mathrm{C}_{27} \mathrm{H}_{25} \mathrm{~N}_{3} \mathrm{O}_{2}$ (423.19): 76.57\% C, 5.95\% H, 9.92\% N; Found: $76.59 \%$ C, $5.94 \% \mathrm{H}, 9.91 \% \mathrm{~N}$.

1-[2-(1H-Benzimidazol-1-yl)acetyl]-3-ethyl-2,6-diphenylpiperidin-4-one (22). Yield = 83\%, m.p. $=183{ }^{\circ} \mathrm{C} .{ }^{1} \mathrm{H}$ NMR $\left(400 \mathrm{MHz}, \mathrm{CDCl}_{3}\right): 7.78\left(\mathrm{~d}, 1 \mathrm{H}, J_{\mathrm{d}, \mathrm{e}}=7.69, \mathrm{H}-\mathrm{d}\right), 7.75$ (s, 1H, H-b), 7.37-7.32 (m, $6 \mathrm{H}$, aromatic protons), 7.27-7.19 (m, 2H, H-f/H-e), 7.16-7.14 (m, 4H, ortho protons), $6.81\left(\mathrm{~d}, 1 \mathrm{H}, J_{\mathrm{g}, \mathrm{f}}=7.32, \mathrm{H}-\mathrm{g}\right), 6.13$ (bs, 1H, H-2), 5.48 (bs, 1H, H-6), 4.83 (d, 1H, $\left.{ }^{2} J_{\mathrm{Hx}, \mathrm{Hy}}=16.84,-\mathrm{COCH} H \mathrm{x}\right), 4.63\left(\mathrm{~d}, 1 \mathrm{H},{ }^{2} J_{\mathrm{Hy}, \mathrm{Hx}}=16.84,-\mathrm{COCH} H \mathrm{y}\right), 3.08\left(\mathrm{q}, 1 \mathrm{H},{ }^{3} J_{3 \mathrm{a}, 2 \mathrm{a}}=3.51\right.$, H-3ax), $2.99\left(\mathrm{dd}, 1 \mathrm{H},{ }^{2} J_{5 \mathrm{a}, 5 \mathrm{e}}=17.58,{ }^{3} J_{5 \mathrm{a}, 6 \mathrm{a}}=9.89, \mathrm{H}-5 \mathrm{ax}\right), 2.71\left(\mathrm{dd}, 1 \mathrm{H},{ }^{2} J_{5 \mathrm{e}, 5 \mathrm{a}}=17.58,{ }^{3} J_{5 \mathrm{e}, 6 \mathrm{a}}=\right.$ 5.49, H-5eq), 1.79-1.57 (m, 2H, $-\mathrm{CH}_{2} \mathrm{CH}_{3}$ at C-3), 1.06 (t, $\mathrm{J}_{\mathrm{Me}, \mathrm{H}}=7.34,3 \mathrm{H},-\mathrm{CH}_{2} \mathrm{CH}_{3}$ at C-3). ${ }^{13} \mathrm{C}$ NMR (400 MHz, CDCl 3 /DMSO- $\left.d_{6}\right): 208.17$ (C-4), $168.84(\mathrm{~N}-\mathrm{C}=\mathrm{O}), 143.79$ (C-b), 143.09 (C-i), 141.19 (C-6'), 140.51 (C-2'), 133.83 (C-h), 129.39-126.00 (aryl carbons), 122.91 (C-e), 122.07 
(C-f), 120.16 (C-d), 108.83 (C-g), 56.69 (C-2/C-6), 51.67 (C-3), 46.72 (-COCH$\left.)_{2}\right), 44.83$ (C-5), $22.83\left(-\mathrm{CH}_{2} \mathrm{CH}_{3}\right.$ at C-3), $11.60\left(-\mathrm{CH}_{2} \mathrm{CH}_{3}\right.$ at C-3). Anal. cald. for $\mathrm{C}_{28} \mathrm{H}_{27} \mathrm{~N}_{3} \mathrm{O}_{2}$ (437.21): $76.86 \%$ C, $6.22 \% \mathrm{H}, 9.60 \% \mathrm{~N}$; Found: $76.84 \% \mathrm{C}, 6.23 \% \mathrm{H}, 9.60 \% \mathrm{~N}$.

1-[2-(1 H-Benzimidazol-1-yl)acetyl]-3,5-dimethyl-2,6-diphenylpiperidin-4-one (23). Yield = 87\%, m.p. $178-180{ }^{\circ} \mathrm{C} .{ }^{1} \mathrm{H}$ NMR (400 MHz, $\mathrm{CDCl}_{3}$ ): 7.72 (d, $1 \mathrm{H}, J_{\mathrm{d}, \mathrm{e}}=7.69, \mathrm{H}-\mathrm{d}$ ), 7.68 (s, $1 \mathrm{H}$, $\mathrm{H}-\mathrm{b}), 7.38-7.10(\mathrm{~m}, 12 \mathrm{H}$, aromatic protons and $\mathrm{H}-\mathrm{f} / \mathrm{H}-\mathrm{e}), 6.69\left(\mathrm{~d}, 1 \mathrm{H}, J_{\mathrm{g}, \mathrm{f}}=7.69, \mathrm{H}-\mathrm{g}\right), 5.44$ (bs, $2 \mathrm{H}, \mathrm{H}-2 / \mathrm{H}-6), 4.71$ (s, 2H, $-\mathrm{COCH}_{2}$ ), 3.19 (q, 2H, $\left.{ }^{3} J_{5 \mathrm{a}, 6 \mathrm{a}}={ }^{3} J_{3 \mathrm{a}, 2 \mathrm{a}}=6.87, \mathrm{H}-3 \mathrm{ax} / \mathrm{H}-5 \mathrm{ax}\right), 1.10(\mathrm{~d}$, $6 \mathrm{H}, J_{\mathrm{Me}, \mathrm{H}}=6.59, \mathrm{CH}_{3}$ at $\mathrm{C}-3$ and C-5). ${ }^{13} \mathrm{C} \mathrm{NMR}\left(400 \mathrm{MHz}, \mathrm{CDCl}_{3}\right): 210.37(\mathrm{C}-4), 169.00(\mathrm{~N}-$ $\mathrm{C}=\mathrm{O}$ ), 143.84 (C-b), 142.98 (C-i), 140.61 (C-2'/C-6'), 129.21-127.46 (aryl carbons), 133.82 (Ch), 122.94 (C-e), 122.06 (C-f), 120.09 (C-d), 108.80 (C-g), 61.21 (C-2/C-6), 46.73 (-COCH ${ }_{2}$ ), 45.25 (C-3/C-5), $14.11\left(\mathrm{CH}_{3}\right.$ at C-3/C-5). Anal. cald. for $\mathrm{C}_{28} \mathrm{H}_{27} \mathrm{~N}_{3} \mathrm{O}_{2}$ (437.21): 76.86\% C, 6.22\% H, $9.60 \% \mathrm{~N}$; Found: $76.87 \% \mathrm{C}, 6.21 \% \mathrm{H}, 9.58 \% \mathrm{~N}$.

1-[2-(1H-Benzimidazol-1-yl)acetyl]-3-methyl-2,6-bis(p-fluorophenyl)piperidin-4-one (24). Yield $=90 \%$, m.p. $119-120{ }^{\circ} \mathrm{C} .{ }^{1} \mathrm{H}$ NMR $\left(400 \mathrm{MHz}, \mathrm{CDCl}_{3}\right): 7.79$ (d, $\left.1 \mathrm{H}, J_{\mathrm{d}, \mathrm{e}}=6.96, \mathrm{H}-\mathrm{d}\right), 7.78$ (s, $1 \mathrm{H}, \mathrm{H}-\mathrm{b}), 7.28-7.03(\mathrm{~m}, 10 \mathrm{H}$, aromatic protons and $\mathrm{H}-\mathrm{f} / \mathrm{H}-\mathrm{e}), 6.79\left(\mathrm{~d}, 1 \mathrm{H}, J_{\mathrm{g}, \mathrm{f}}=7.32, \mathrm{H}-\mathrm{g}\right)$, 6.01 (bs, 1H, H-6), 5.29 (bs, 1H, H-2), 4.77 (d, 1H, ${ }^{2} J_{\mathrm{Hx}, \mathrm{Hy}}=16.84$, -COCH Hx), 4.67 (d, $1 \mathrm{H}$, $\left.{ }^{2} J_{\mathrm{Hy}, \mathrm{Hx}}=16.84,-\mathrm{COCHHy}\right), 3.19\left(\mathrm{dd}, 1 \mathrm{H},{ }^{2} J_{5 \mathrm{a}, 5 \mathrm{e}}=18.31,{ }^{3} J_{5 \mathrm{a}, 6 \mathrm{a}}=5.13, \mathrm{H}-5 \mathrm{ax}\right), 3.05(\mathrm{q}, 1 \mathrm{H}$, $\left.{ }^{3} J_{3 \mathrm{a}, 2 \mathrm{a}}=7.05, \mathrm{H}-3 \mathrm{ax}\right), 2.88\left(\mathrm{dd}, 1 \mathrm{H},{ }^{2} J_{5 \mathrm{e}, 5 \mathrm{a}}=18.49,{ }^{3} J_{5 \mathrm{e}, 6 \mathrm{a}}=6.04, \mathrm{H}-5 \mathrm{eq}\right), 1.07\left(\mathrm{~d}, J_{\mathrm{Me}, \mathrm{H}}=6.59\right.$, $3 \mathrm{H}, \mathrm{CH}_{3}$ at C-3). ${ }^{13} \mathrm{C}$ NMR (400 MHz, $\left.\mathrm{CDCl}_{3}\right): 207.56$ (C-4), 168.58 (N-C=O), 163.39 (C-6"'”), 160.91 (C-2"'"), 136.48/ 136.45 (C-6'), 136.27/136.24 (C-2'), 129.11/129.03 (C-6"), 128.49/128.42 (C-2"), 116.11/ 116.08 (C-2"'), 116.29/116.24 (C-6"”), 143.81 (C-b), 143.05 (Ci), 133.85 (C-h), 123.17 (C-e), 122.32 (C-f), 120.23 (C-d), 108.79 (C-g), 61.65 (C-2), 53.25 (C6), $46.86\left(-\mathrm{COCH}_{2}\right), 46.28$ (C-3), $42.62(\mathrm{C}-5), 13.24\left(\mathrm{CH}_{3}\right.$ at C-3). Anal. cald. for $\mathrm{C}_{27} \mathrm{H}_{23} \mathrm{~F}_{2} \mathrm{~N}_{3} \mathrm{O}_{2}$ (459.18): $76.86 \% \mathrm{C}, 6.22 \% \mathrm{H}, 9.60 \% \mathrm{~N}$; Found: $76.87 \% \mathrm{C}, 6.21 \% \mathrm{H}, 9.58 \% \mathrm{~N}$.

\section{1-[2-(1 H-Benzimidazol-1-yl)acetyl]-3,5-dimethyl-2,6-bis(p-fluorophenyl)piperidin-4-one}

(25). Yield $=92 \%, \mathrm{mp} 136-138{ }^{\circ} \mathrm{C} .{ }^{1} \mathrm{H}$ NMR $\left(400 \mathrm{MHz}, \mathrm{CDCl}_{3}\right): 7.78(\mathrm{~s}, 1 \mathrm{H}, \mathrm{H}-\mathrm{b}), 7.72(\mathrm{~d}, 1 \mathrm{H}$, $\left.J_{\mathrm{d}, \mathrm{e}}=7.69, \mathrm{H}-\mathrm{d}\right), 7.25-6.99(\mathrm{~m}, 10 \mathrm{H}$, aromatic protons and $\mathrm{H}-\mathrm{f} / \mathrm{H}-\mathrm{e}), 6.76\left(\mathrm{~d}, 1 \mathrm{H}, J_{\mathrm{g}, \mathrm{f}}=7.32, \mathrm{H}-\right.$ g), 5.41 (bs, $2 \mathrm{H}, \mathrm{H}-2 / \mathrm{H}-6$ ), 4.72 (s, $2 \mathrm{H},-\mathrm{COCH}_{2}$ ), 3.12 (q, $2 \mathrm{H},{ }^{3} J_{5 \mathrm{a}, 6 \mathrm{a}}={ }^{3} J_{3 \mathrm{a}, 2 \mathrm{a}}=6.77, \mathrm{H}-3 \mathrm{ax} / \mathrm{H}-$ $5 \mathrm{ax}), 1.09\left(\mathrm{~d}, 6 \mathrm{H}, J_{\mathrm{Me}, \mathrm{H}}=6.96, \mathrm{CH}_{3}\right.$ at $\mathrm{C}-3$ and $\left.\mathrm{C}-5\right) .{ }^{13} \mathrm{C} \mathrm{NMR}\left(400 \mathrm{MHz}, \mathrm{CDCl}_{3}\right): 209.75(\mathrm{C}-4)$, 168.93 (N-C=O), 163.49/163.39 (C-6"'”), 161.01/160.92 (C-2'”'), 143.79 (C-b), 143.09 (C-i), 136.41/136.38 (C-2'/C-6'), 133.79 (C-h), 129.29/129.21 (C-6"), 129.11/129.03 (C-2"), 116.29/116.08 (C-6"”), 115.85/ 115.75 (C-2"”), 123.18 (C-e), 122.32 (C-f), 120.36 (C-d), 108.70 (C-g), 60.71 (C-2/C-6), $46.86\left(-\mathrm{COCH}_{2}\right), 45.49(\mathrm{C}-3 / \mathrm{C}-5), 14.21\left(\mathrm{CH}_{3}\right.$ at C-3/C-5). For $\mathrm{C}_{28} \mathrm{H}_{25} \mathrm{~F}_{2} \mathrm{~N}_{3} \mathrm{O}_{2}$ (473.19): $71.02 \%$ C, 5.32\% H, 8.87\% N; Found: $71.00 \% \mathrm{C}, 5.32 \% \mathrm{H}, 8.88 \% \mathrm{~N}$.

1-[2-(1H-Benzimidazol-1-yl)acetyl]-3-methyl-2,6-bis(p-chlorophenyl)piperidin-4-one (26). Yield $=85 \%$, m.p. $140-142{ }^{\circ} \mathrm{C}$ (decomposition). ${ }^{1} \mathrm{H}$ NMR $\left(400 \mathrm{MHz}, \mathrm{CDCl}_{3}\right): 7.79$ (s, $2 \mathrm{H}, \mathrm{H}-$ $\mathrm{d} / \mathrm{H}-\mathrm{b}), 7.38$ (d, $2 \mathrm{H}, J=8.42$, proton at C-6"'), 7.35 (d, $2 \mathrm{H}, J=7.35$, proton at C-2"'), 7.20 (d, $2 \mathrm{H}, J=8.43$, proton at C-6"), 7.29-7.24 (m, $2 \mathrm{H}, \mathrm{H}-\mathrm{f} / \mathrm{H}-\mathrm{e}), 7.07$ (d, $2 \mathrm{H}, J=8.42$, proton at C-2"), $6.79\left(\mathrm{~d}, 1 \mathrm{H}, J_{\mathrm{g}, \mathrm{f}}=6.96, \mathrm{H}-\mathrm{g}\right), 6.01(\mathrm{bs}, 1 \mathrm{H}, \mathrm{H}-6), 5.28(\mathrm{bs}, 1 \mathrm{H}, \mathrm{H}-2), 4.78\left(\mathrm{~d}, 1 \mathrm{H},{ }^{2} J_{\mathrm{Hx}, \mathrm{Hy}}=16.84\right.$, $-\mathrm{COCH} H \mathrm{x}), 4.68\left(\mathrm{~d}, 1 \mathrm{H},{ }^{2} J_{\mathrm{Hy}, \mathrm{Hx}}=16.84,-\mathrm{COCH} H \mathrm{y}\right), 3.16\left(\mathrm{dd}, 1 \mathrm{H},{ }^{2} J_{5 \mathrm{a}, 5 \mathrm{e}}=18.12,{ }^{3} J_{5 \mathrm{a}, 6 \mathrm{a}}=5.31\right.$, 
H-5ax), $3.02\left(\mathrm{q}, 1 \mathrm{H},{ }^{3} J_{3 \mathrm{a}, 2 \mathrm{a}}=7.05, \mathrm{H}-3 \mathrm{ax}\right), 2.87\left(\mathrm{dd}, 1 \mathrm{H},{ }^{2} J_{5 \mathrm{e}, 5 \mathrm{a}}=18.16,{ }^{3} J_{5 \mathrm{e}, 6 \mathrm{a}}=5.89, \mathrm{H}-5 \mathrm{eq}\right)$, $1.07\left(\mathrm{~d}, J_{\mathrm{Me}, \mathrm{H}}=6.96,3 \mathrm{H}, \mathrm{CH}_{3}\right.$ at C-3). ${ }^{13} \mathrm{C} \mathrm{NMR}\left(400 \mathrm{MHz}, \mathrm{CDCl}_{3}\right): 207.26(\mathrm{C}-4), 168.69(\mathrm{~N}-$ $\mathrm{C}=\mathrm{O}$ ), 143.79 (C-b), 143.18 (C-i), 138.92 (C-2'), 139.16 (C-6'), 133.88 (C-h), 134.57 (C-6'”'), 134.46 (C-2"''), 129.61-128.12 (aromatic carbons), 123.36 (C-e), 122.51 (C-f), 120.50 (C-d), 108.81 (C-g), 61.88 (C-2), 53.50 (C-6), $47.03\left(-\mathrm{COCH}_{2}\right), 46.24$ (C-3), 42.80 (C-5), $13.34\left(\mathrm{CH}_{3}\right.$ at C-3). Anal. cald. for $\mathrm{C}_{27} \mathrm{H}_{23} \mathrm{Cl}_{2} \mathrm{~N}_{3} \mathrm{O}_{2}$ (491.12): $65.86 \% \mathrm{C}, 4.71 \% \mathrm{H}, 8.53 \% \mathrm{~N}$; Found: $71.00 \% \mathrm{C}$, $5.32 \% \mathrm{H}, 8.88 \% \mathrm{~N}$.

\section{1-[2-(1H-Benzimidazol-1-yl)acetyl]-3,5-dimethyl-2,6-bis(p-chlorophenyl)piperidin-4-one}

(27). Yield $=88 \%$, m.p. $120-121{ }^{\circ} \mathrm{C} .{ }^{1} \mathrm{H}$ NMR $\left(400 \mathrm{MHz}, \mathrm{CDCl}_{3}\right): 7.78$ (d, 1H, J,e $=7.69$, H-d), 7.77 (s, 1H, H-b), 7.38 (d, 4H, $J=8.78$, protons at C-2"'/C-6"'), 7.28-7.20 (m, 2H, H-f/H-e), 7.14 (d, 4H, $J=8.42$, protons at C-2"/C-6”), 6.77 (d, 1H, $\left.J_{\mathrm{g}, \mathrm{f}}=7.69, \mathrm{H}-\mathrm{g}\right), 5.39$ (bs, 2H, H-2/H6), $4.71\left(\mathrm{~s}, 2 \mathrm{H},-\mathrm{COCH}_{2}\right), 3.13\left(\mathrm{q}, 2 \mathrm{H},{ }^{3} J_{5 \mathrm{a}, 6 \mathrm{a}}={ }^{3} J_{3 \mathrm{a}, 2 \mathrm{a}}=6.77, \mathrm{H}-3 \mathrm{ax} / \mathrm{H}-5 \mathrm{ax}\right), 1.12\left(\mathrm{~d}, 6 \mathrm{H}, J_{\mathrm{Me}, \mathrm{H}}=\right.$ 6.96, $\mathrm{CH}_{3}$ at C-3 and C-5). ${ }^{13} \mathrm{C}$ NMR (400 MHz, $\left.\mathrm{CDCl}_{3}\right): 209.39$ (C-4), $168.88(\mathrm{~N}-\mathrm{C}=\mathrm{O}), 143.76$ (C-b), 143.10 (C-i), 138.89 (C-2'/C-6'), 134.42 (C-2"'”/C-6"'”), 133.75 (C-h), 129.41, 128.83, (aromatic carbons), 123.23 (C-e), 122.37 (C-f), 120.39 (C-d), 108.66 (C-g), 60.79(C-2/C-6), $46.77\left(-\mathrm{COCH}_{2}\right), 45.29(\mathrm{C}-3 / \mathrm{C}-5), 14.16\left(\mathrm{CH}_{3}\right.$ at $\left.\mathrm{C}-3 / \mathrm{C}-5\right)$. Anal. cald. for $\mathrm{C}_{28} \mathrm{H}_{25} \mathrm{Cl}_{2} \mathrm{~N}_{3} \mathrm{O}_{2}$ (505.13): 66.41\% C, 4.98\% H, 8.30\% N; Found: 66.43\% C, 4.97\% H, 8.32\% N.

1-[2-(1H-Benzimidazol-1-yl)acetyl]-3-methyl-2,6-bis(p-bromophenyl)piperidin-4-one (28). Yield $=80 \%$, m.p. $110-112{ }^{\circ} \mathrm{C}$ (decomposition). ${ }^{1} \mathrm{H}$ NMR (400 MHz, $\left.\mathrm{CDCl}_{3}\right): 7.79$ (s, 2H, Hd/H-b), 7.53 (d, 2H, $J=8.42$, proton at C-6"'), 7.49 (d, 2H, $J=8.42$, proton at C-2"'), 7.28-7.20 (m, 2H, H-f/H-e), $7.14(\mathrm{~d}, 1 \mathrm{H}, J=8.42$, proton at C-6”), 7.01 (d, 2H, $J=8.06$, proton at C-2”), $6.78\left(\mathrm{~d}, 2 \mathrm{H}, J_{\mathrm{g}, \mathrm{f}}=6.96, \mathrm{H}-\mathrm{g}\right), 5.95$ (bs, $\left.1 \mathrm{H}, \mathrm{H}-6\right), 5.28$ (bs, $\left.1 \mathrm{H}, \quad \mathrm{H}-2\right), 4.78\left(\mathrm{~d}, 1 \mathrm{H},{ }^{2} J_{\mathrm{Hx}, \mathrm{Hy}}=\right.$ 16.84, -COCHHx), 4.69 (d, $1 \mathrm{H},{ }^{2} J_{\mathrm{Hy}, \mathrm{Hx}}=16.84$, -COCHHy), $3.16\left(\mathrm{dd}, 1 \mathrm{H},{ }^{2} J_{5 \mathrm{a}, 5 \mathrm{e}}=18.31,{ }^{3} J_{5 \mathrm{a}, 6 \mathrm{a}}\right.$ $=5.13, \mathrm{H}-5 \mathrm{ax}), 3.02\left(\mathrm{q}, 1 \mathrm{H},{ }^{3} J_{3 \mathrm{a}, 2 \mathrm{a}}=7.14, \mathrm{H}-3 \mathrm{ax}\right), 2.86\left(\mathrm{dd}, 1 \mathrm{H},{ }^{2} J_{5 \mathrm{e}, 5 \mathrm{a}}=18.49,{ }^{3} J_{5 \mathrm{e}, 6 \mathrm{a}}=6.04, \mathrm{H}-\right.$ 5eq), $1.07\left(\mathrm{~d}, J_{\mathrm{Me}, \mathrm{H}}=6.59,3 \mathrm{H}, \mathrm{CH}_{3}\right.$ at C-3). ${ }^{13} \mathrm{C} \mathrm{NMR}\left(400 \mathrm{MHz}, \mathrm{CDCl}_{3}\right): 207.17$ (C-4), 168.63 $(\mathrm{N}-\mathrm{C}=\mathrm{O}), 143.75$ (C-b), 142.80 (C-i), 139.49 (C-6'), 139.29 (C-2'), 133.66 (C-h), 131.96-128.18 (aromatic carbons), 122.69 (C-6"”), 122.69 (C-e), 121.89 (C-f), 121.81 (C-2"'”), 119.82 (C-d), 108.82 (C-g), 61.45 (C-2), 52.90 (C-6), $46.56\left(-\mathrm{COCH}_{2}\right), 45.87$ (C-3), 41.97 (C-5), $12.94\left(\mathrm{CH}_{3}\right.$ at C-3). Anal. cald. for $\mathrm{C}_{27} \mathrm{H}_{23} \mathrm{Br}_{2} \mathrm{~N}_{3} \mathrm{O}_{2}$ (579.02): 55.79\% C, 3.99\% H, 7.23\% N; Found: 55.77\% C, $4.00 \% \mathrm{H}, 7.22 \% \mathrm{~N}$.

\section{1-[2-(1H-Benzimidazol-1-yl)acetyl]-3,5-dimethyl-2,6-bis( $p$-bromophenyl)piperidin-4-one}

(29). Yield $=81 \%$, m.p. $170{ }^{\circ} \mathrm{C} .{ }^{1} \mathrm{H}$ NMR $\left(400 \mathrm{MHz}, \mathrm{CDCl}_{3}\right): 7.78$ (d, $\left.1 \mathrm{H}, J_{\mathrm{d}, \mathrm{e}}=7.69, \mathrm{H}-\mathrm{d}\right), 7.77$ (s, 1H, H-b), 7.53 (d, 4H, $J=8.42$, protons at C-2"'/C-6"'), 7.28-7.23 (m, 2H, H-f/H-e), 7.08 (d, $4 \mathrm{H}, J=8.42$, protons at C-2"/C-6"), 6.75 (d, 1H, $\left.J_{\mathrm{g}, \mathrm{f}}=6.96, \mathrm{H}-\mathrm{g}\right), 5.38$ (bs, 2H, H-2/H-6), 4.72 $\left(\mathrm{s}, 2 \mathrm{H},-\mathrm{COCH}_{2}\right), 3.12\left(\mathrm{q}, 2 \mathrm{H},{ }^{3} J_{5 \mathrm{a}, 6 \mathrm{a}}={ }^{3} J_{3 \mathrm{a}, 2 \mathrm{a}}=6.77, \mathrm{H}-3 \mathrm{ax} / \mathrm{H}-5 \mathrm{ax}\right), 1.12\left(\mathrm{~d}, 6 \mathrm{H}, J_{\mathrm{Me}, \mathrm{H}}=6.96\right.$, $\mathrm{CH}_{3}$ at $\mathrm{C}-3$ and $\left.\left.\mathrm{C}-5\right) .{ }^{13} \mathrm{C} \mathrm{NMR}\left(400 \mathrm{MHz}^{\mathrm{CDCl}}\right)_{3}\right): 209.33(\mathrm{C}-4), 168.87(\mathrm{~N}-\mathrm{C}=\mathrm{O}), 143.77(\mathrm{C}-$ b), 143.05 (C-i), 139.39 (C-2'/C-6'), 133.72 (C-h), 132.36, 129.12 (aromatic carbons), 123.23 (C-e), 122.49 (C-f), 120.34 (C-d), 108.66 (C-g); 60.84 (C-2/C-6); 46.72 (-COCH $)$; 45.21 (C3/C-5); $14.14\left(\mathrm{CH}_{3}\right.$ at C-3/C-5). Anal. cald. for $\mathrm{C}_{28} \mathrm{H}_{25} \mathrm{Br}_{2} \mathrm{~N}_{3} \mathrm{O}_{2}$ (593.03): 56.49\% C, 4.23\% $\mathrm{H}$, $7.06 \%$ N; Found: $56.48 \%$ C, $4.22 \%$ H, $7.07 \%$ N. 


\section{1-[2-(1H-Benzimidazol-1-yl)acetyl]-3,5-dimethyl-2,6-bis( $p$-methylphenyl)piperidin-4-one}

(30). Yield $=87 \%$, m.p. $138-140{ }^{\circ} \mathrm{C} .{ }^{1} \mathrm{H}$ NMR $\left(400 \mathrm{MHz}, \mathrm{CDCl}_{3}\right): 7.77$ (d, 1H, $J_{\mathrm{d}, \mathrm{e}}=7.69$, H-d), 7.71 (s, 1H, H-b), 7.26-7.21 (m, 2H, H-f/H-e), 7.18 (d, 4H, $J=8.06$, protons at C-2"'/C-6"'), 7.09 (d, 4H, $J=8.06$, protons at C-2"/C-6"), 6.76 (d, 1H, J,f $=7.69, \mathrm{H}-\mathrm{g}), 5.42$ (bs, 2H, H-2/H6), $4.72\left(\mathrm{~s}, 2 \mathrm{H},-\mathrm{COCH}_{2}\right), 3.21\left(\mathrm{q}, 2 \mathrm{H},{ }^{3} J_{5 \mathrm{a}, 6 \mathrm{a}}={ }^{3} J_{3 \mathrm{a}, 2 \mathrm{a}}=6.68, \mathrm{H}-3 \mathrm{ax} / \mathrm{H}-5 \mathrm{ax}\right), 2.37$ (s, 6H, $\mathrm{CH}_{3}$ at C-2"'" and C-6"'"), $1.12\left(\mathrm{~d}, 6 \mathrm{H}, \mathrm{J}_{\mathrm{Me}, \mathrm{H}}=6.96, \mathrm{CH}_{3}\right.$ at $\mathrm{C}-3$ and $\left.\mathrm{C}-5\right) .{ }^{13} \mathrm{C} \mathrm{NMR}\left(400 \mathrm{MHz}, \mathrm{CDCl}_{3}\right)$ : 210.73 (C-4), 168.99 (N-C=O), 143.88 (C-b), 143.17 (C-i), 138.03 (C-2'/C-2'"'), 137.39 (C6'/C-6"'"), 133.89 (C-h), 129.68, 127.41 (aromatic carbons), 122.88 (C-e), 122.03 (C-f), 120.22 (C-d), 108.86 (C-g), 61.03 (C-2/C-6), 46.78 (-COCH $), 45.35$ (C-3/C-5), $20.93\left(\mathrm{CH}_{3}\right.$ at C-2"'”/C6"'’), $14.13\left(\mathrm{CH}_{3}\right.$ at C-3/C-5). Anal. cald. for $\mathrm{C}_{30} \mathrm{H}_{31} \mathrm{~N}_{3} \mathrm{O}_{2}$ (465.24): 77.39\% C, 6.71\% $\mathrm{H}, 9.03 \%$ $\mathrm{N}$; Found: $77.15 \% \mathrm{C}, 6.48 \% \mathrm{H}, 9.30 \% \mathrm{~N}$.

\section{Crystal structure analysis}

Fine white crystals of 1-chloroacetyl-3,5-dimethyl-2,6-bis( $p$-methylphenyl)piperidin-4-one (20) was obtained by recrystallization in absolute ethanol. Crystal data and structural refinements were given in Table S2 (refer in supplementary file). Crystal data have been deposited to the Cambridge Crystallographic Data Centre (CCDC No. 683392).

\section{Antimicrobial activity}

Antimicrobial activity of the synthesized compounds was tested by the cup or well method. ${ }^{28}$ Solutions of test compounds were prepared in DMSO at a concentration of $100 \mu \mathrm{g} / \mathrm{mL}$. Whatman No.1 discs (about $6 \mathrm{~mm}$ in diameter) were impregnated in the test compounds for about one hour prior to test (paper disc impregnated in DMSO only served as negative controls). Commercially available drug disc $(10 \mu \mathrm{g} /$ disc $)$ was used as positive reference standard. The discs were placed on the inoculated agar plates and incubated at $37 \pm 1{ }^{\circ} \mathrm{C}$ for bacteria and $28 \pm 1{ }^{\circ} \mathrm{C}$ for fungi. Antimicrobial activity was evaluated by measuring the growth inhibition zone ( $\mathrm{mm}$ ) against the tested organisms after 24 hours for bacteria and 72 hours for fungi.

\section{Supplementary Information Available}

NMR, crystal data, mass spectral data and individual mass fragmentations pattern are available.

\section{Acknowledgements}

This research work was supported by the second stage of BK21 program and Pukyong National University in the 2007 Post-Doc program. 


\section{References}

1. Stewart, W. E.; Siddal, T. H. Chem. Rev. 1970, 70, 517.

2. (a) Aridoss, G.; Parthiban. P.; Ramachandran, R.; Prakash, M.; Kabilan, S. Jeong, Y. T. Eur. J. Med. Chem. 2008, doi:10.1016/j.ejmech.2008.03.031. (b) Aridoss, G.; Balasubramanian, S.; Parthiban. P.; Kabilan, S. Eur. J. Med. Chem. 2007, 42, 851. (c) Aridoss, G.; Balasubramanian, S.; Parthiban. P.; Ramachandran, R.; Kabilan, S. Med. Chem. Res. 2007, $16,188$.

3. Aridoss, G.; Balasubramanian, S.; Parthiban, P.; Kabilan, S. Spectrochim. Acta Part A 2007, 68(5), 1153. (b) Aridoss, G. Ph.D. Thesis, Annamalai University, India, 2007.

4. Casy, A.; Coates, J.; Rostron, J. C. J. Pharm. Pharmacol. 1976, 28, 106.

5. Wahe, H.; Asobo, P. F.; Cherkasov, R. A.; Nkengfack, A. E.; Folefoc, G. N.; Fomum, Z. T.; Doepp D. ARKIVOC 2003, (xiv), 170.

6. Göker, H.; Kuş, C.; Boykin, D. W.; Yildiz, S.; Altanlar, N. Bioorg. Med. Chem. 2002, 10, 2589.

7. (a) Göker, H.; Özden, S.; Yıldız, S.; Boykin, D. W. Eur. J. Med. Chem. 2005, 40,1062. (b) Andrzejewska, M.; Yépez-Mulia, L.; Cedillo-Rivera, R.; Tapia, A.; Vilpo, L.; Vilpo, J.; Kazimierczuk, Z. Eur. J. Med. Chem. 2002, 37, 973. (c) Özden, S.; Atabey, D.; Y1ldı, S.; Göker, H. Bioorg. Med. Chem. 2005, 13, 1587.

8. Ramla, M. M.; Omar, M. A.; El-Khamry, A.-M.; El-Diwani, H. I. Bioorg. Med. Chem. 2006, 14, 7324.

9. (a) He, Y.; Wu, B.; Yang, J.; Robinson, D.; Risen, L.; Ranken, R. Blyn, L.; Sheng, S.; Swayze, E. E. Bioorg. Med. Chem. Lett. 2003, 13, 3253. (b) He, Y.; Yang, J.; Wu, B.; Risen, L.; Swayze, E. E. Bioorg. Med. Chem. Lett. 2004, 14, 1217.

10. Mathias, L. J.; Burkett, D. Tetrahedron Lett. 1979, 4709. (b) Kikugawa, Y. Synthesis, 1981, 124. (c) Savignac, A.; Roques, C.; Hinedi, M.; Michel, G.; Lattes, A. Eur. J. Med. Chem. 1990, 25, 440. (d) Khalafi-Nezhad, A.; Soltani Rad, M. N.; Mohabatkar, H. Asrari, Z.; Hemmateenejad, B. Bioorg. Med. Chem. 2005, 13, 1932.

11. Ramla, M. M.; Omar, M. A.; Tokuda, H.; El-Diwani, H. I. Bioorg. Med. Chem. 2007, 15, 6489.

12. (a) Thompson, W. W.; Shay, D. K.; Weintraub, E.; Brammer, L.; Cox, N.; Anderson, L. J.; Fukuda, K. JAMA 2003, 289, 179. (b) Wang, X. A.; Cianci, C. W.; Yu, K. L.; Combrink, K. D.; Thuring, J. W.; Zhang, Y.; Civiello, R. L.; Kadow, K. F.; Roach, J.; Li, Z.; Langley, D. R.; Krystal, M.; Meanwell, N. A. Bioorg. Med. Chem. Lett. 2007, 17, 4592.

13. Katritzky, A. R.; Singh, S. K. ARKIVOC 2003, (xiii), 68.

14. Güven, Ö. Ö.; Erdoğan, T.; Gökerb, H.; Yıldızc, S. Bioorg. Med. Chem. Lett. 2007, 17, 2233.

15. Silverstein, R. M.; Bassler, G. C.; Morrill, T. Spectrophotometric Identification of Organic Compounds, $5^{\text {th }}$ Edn., Wiley: New York, 1991, pp 174-175. 
16. Günther H. In NMR Spectroscopy: Basic Principles, Concepts, and Applications in Chemistry, $2^{\text {nd }}$ Edn., Wiley: Chichester, 1995, p 82.

17. McConnell, H. M. J. Chem. Phys. 1957, 27, 226.

18. Martin, N. H.; Allen, N. W.; Brown, J. D.; Kmiec, Jr. D. M.; Vo, L. J. Mol. Graphics Modell. 2003, 22, 127.

19. (a) Tafazzoli, M.; Ziyaei-Halimjani, A.; Ghiasi, M.; Fattahi, M.; Saidi, M. R. J. Mol. Struct. 2008, 886, 24. (b) Suarez, C.; Nicholas, E. J.; Bowman, M. R. J. Phys. Chem. A 2003, 107, 3024.

20. Binsch, G. Top. Stereochem. 1968, 3, 97. (b) LeCam, P. Sandstreom, Chem. Scr. 1971, 1, 65. (c) Yousif, G. A.; Roberts, J. D. J. Am. Chem. Soc. 1968, 90, 6428. (d) Lambert, J. B.; Keske, R. G.; Carhart, R. E.; Joranovich, A. P. J. Am. Chem. Soc. 1967, 89, 3761. (e) Anet, F. A. L.; Chmurny, G.; Krane, N. J. J. Am. Chem. Soc. 1973, 95, 4423. (f) Bernard, M.; Canuel, L.; St-Jacques, M. ibid. 1974, 96, 2929.

21. Lewin, A. H.; Ftucht, M. Org. Magn. Reson. 1975, 7, 206. (b) Ramalingam, K.; Berlin, K. D.; Satyamurthy, N.; Sivakumar, R. J. Org. Chem. 1979, 44, 471. (c) Sivasubramanian, S.; Sundharavadivelu, M.; Arumugam, N. Indian J. Chem. 1981, 20B, 878.

22. Lunazzi, L.; Maciantelli, D. J. Chem. Soc., Perkin Trans. II 1981, 406. (b) Lunazzi, L.; Maciantelli, D.; Tassi, D.; Dondoni, A. J. Chem. Soc., Perkin Trans. 1980, 2, 717.

23. Clayden, J.; Pink, J. H. Angew. Chem. Int. Ed. 1998, 37, 1937.

24. SDBS No.1393HSP-02-924 (Online spectral database for organic compounds).

25. Gayathri, D.; Velmurugan, D.; Aridoss, G.; Kabilan, S.; Ravikumar, K. Acta Cryst. 2008, E64, o429.

26. Aridoss, G.; Balasubramanian, S.; Parthiban. P.; Kabilan, S. Eur. J. Med. Chem. 2006, 41, 268.

27. Noller, C. R.; Baliah, V. J. Am. Chem. Soc. 1948, 70, 3853.

28. (a) James, G.; Gappuccino; Sherman, N. Microbiology, A Laboratory Manual, $3^{\text {rd }}$ Edn., The Benjamin/Cummings Publishing Company: California, 1992, pp 77-80. (b) Murray, P. R.; Baron, E. J.; Pfaller, M. A.; Tenover, F. C.; Yolke, R. H. In Manual of Clinical Microbiology, Vol. 6, ASM, Washington DC, 1995. 